\title{
Extraterritoriality, Nationality, and Empire in the Persianate World, 1890-1940
}

\author{
H. Lyman Stebbins \\ La Salle University, Philadelphia, Pennsylvania, USA \\ stebbins@lasalle.edu
}

\begin{abstract}
Extraterritoriality and nationality were crucial to the legal landscape of the Late Persianate world and relations between Iran and British India. Extraterritoriality not only protected British subjects from Persian prosecution but also afforded the British Empire the means to rule Indians in lands beyond the Raj. Iran's opposition to extraterritoriality led to laws that expanded Iranian nationality to include many Indians living in Iran and the Iranian diaspora living in India-who often navigated these rules as it best suited their interests. These developments reveal the significance of imperialism and state building to the emergence of modern international law and the fate of the Persianate world.
\end{abstract}

\section{Keywords}

extraterritoriality - nationality - Persianate - Iran - (British) India

\section{Introduction}

On the afternoon of 9 November 1893 three British subjects were playing cricket in the Persian Gulf port of Bushihr. ${ }^{1}$ About twenty Iranian spectators had gathered. The batsman, Mr. Daniels, a clerk employed by the mercantile firm of Messrs. Grey, Paul \& Company, deflected a ball into the net behind him. A young boy named Muhammad Riza was standing directly behind the net.

1 Crawford to Kārguzāā, 18 December 1893, Fo 248/567. 
The ball hit him in the stomach, and he cried out in pain. Other spectators comforted him and walked him home, another boy holding his hand. The following day, however, Muhammad Riza died. His father, Mashhadi Haji Sabbagh, appealed to the local authorities and to the imām-ijum'ah, the state-appointed leader of the Friday prayers, who demanded monetary compensation (diyah) from Daniels. As a British subject, Daniels, however, enjoyed extraterritoriality, or exemption from Persian jurisdiction and criminal prosecution. On 26 January 1894, the kārguz $\bar{a} r,{ }^{2}$ the agent of the Iranian Ministry of Foreign Affairs in Bushihr, wrote the British resident and consul-general to reach a settlement (Figure 1). ${ }^{3}$ The matter was soon under discussion between the British legation and Qajar authorities in Tehran.

The nineteenth and early twentieth centuries witnessed the creation of Iran's modern "frontiers," their "fictions," and their "frictions." " These borders were not only territorial and ideological ones but also legal and jurisdictional. As commerce and empire bound Iran and British India together, merchants, migrants, and officials navigated these overlapping, porous boundaries. Extraterritoriality and nationality laws were efforts to disentangle and clarify these lines. Merchants in the Indian Ocean and Mediterranean had long enjoyed various kinds of legal autonomy. ${ }^{5}$ The Safavids extended extraterritoriality to English and Dutch merchants in the seventeenth century. ${ }^{6}$ Beginning in the 1820 , Russia and Britain consolidated such privileges into a system of

2 For kārguzāar, see three articles by M. Nouraei and V. Martin in the Journal of the Royal Asiatic Society 3rd ser.: "The Role of the 'Karguzar' in the Foreign Relations of State and Society of Iran from the mid-nineteenth century to 1921. Part I: Diplomatic Relations." 15/3 (November 2005): 261-77; "Part II: The 'Karguzar' and Security, the Trade Routes of Iran and Foreign Subjects 1900-1921." 16/1 (April 2006): 29-41; and "Part III: the 'Karguzar' and Disputes over Foreign Trade." 16/2 (July 2006): 151-63; see also G.G. Gilbar, "Resistance to Economic Penetration: The Kārguzār and Foreign Firms in Qajar Iran." International Journal of Middle East Studies 43 (2001): 5-23. For British consuls, see H.L. Stebbins, British Imperialism in Qajar Iran: Consuls, Agents and Influence in the Middle East (London: I.B. Tauris, 2016).

3 Kārguzāar to Wilson, 26 January 1894/18 Rajab 1311, FO 248/590.

4 F. Kashani-Sabet, Frontier Fictions: Shaping the Iranian Nation, 1804-1946 (Princeton: Princeton University Press, 1999); see also F. Kashani-Sabet, "Baluchistan: Nature, Ethnicity, and Empire in Iran's Borderlands." Journal of the Middle East and Africa 4 (2013): 187-204.

5 K.N. Chaudhuri, Trade and Civilisation in the Indian Ocean: An Economic History from the Rise of Islam to 1750 (Cambridge: Cambridge University Press, 1985): 36, 112.

6 See capitulations of 1600, 1623, and 1629 in The Middle East and North Africa in World Politics: A Documentary Record, vol. 1, ed. J.C. Hurewitz (New Haven: Yale University Press, 2nd edition, 1975): 15-8, 22-4; P. Good, "The East India Company's Farmān, 1622-1747." Iranian Studies 52/1-2 (2019): 181-97. 
"legal imperialism."7 Imperialism played a pivotal role in the making of international law. ${ }^{8}$ European jurists and diplomats limited the scope of international law to what they deemed civilized societies and demanded extraterritoriality from allegedly uncivilized ones like Iran. The denial of liberal institutions to British colonies in Asia and Africa and American restrictions on Chinese immigration relied on the same distinction. ${ }^{9}$ Extraterritoriality spurred Iranian nationalism and Pahlavi legal centralization, secularization, and state building. Similar patterns emerged in the Ottoman Empire, Qing China, and Meiji Japan. Extraterritoriality was thus an avenue by which the "fluid, multijurisdictional legal orders" of the early-modern period were eclipsed by a "state-centered legal pluralism" in the nineteenth and twentieth centuries. ${ }^{10}$ Iran has not received much treatment in this broader literature, and its longstanding relationships with India, both before and during British rule there, make it an interesting case study. Iran's journey into the modern international legal order was shaped by the collision of royal, Islamic, and foreign law-in the latter instance British and Anglo-Indian law. As the death of Muhammad Riza reveals, moreover, Qajar officials and the 'ulama' challenged British jurisdiction well before the abolition of extraterritoriality and the promulgation of the Iranian Civil Code (Qanun-i madani) in the first decade of Pahlavi rule.

Extraterritoriality in Iran impacted Britain's Indian subjects along with its European ones. Indian communities in Iran and the Persian Gulf were diffuse and diverse. ${ }^{11}$ Daniels himself was of mixed European and Indian descent. Indian merchants flourished in this region throughout the long nineteenth century, controlling key commodities and bazaar capital, before encountering severe

7 T. Kayaoğlu, Legal Imperialism: Sovereignty and Extraterritoriality in Japan, China, and the Ottoman Empire (New York: Cambridge University Press, 2010); see also A. Gheissari, "Unequal Treaties and the Question of Sovereignty in Imperial Persia." In Struggles for Sovereignty: Non-European Powers in the Age of Empire, ed. H.E. Chehabi and D. Motadel (Oxford: Oxford University Press, forthcoming).

8 A. Anghie, Imperialism, Sovereignty, and the Making of International Law (New York: Cambridge University Press, 2005): 3-7; see also L. Benton, Search for Sovereignty: Law and Geography in European Empires, 1400-1900 (New York: Cambridge University Press, 2010): 276-8.

9 U.S. Mehta, Liberalism and Empire: A Study in Nineteenth-Century British Liberal Thought (Chicago: University of Chicago Press, 1999): 81; A.M. McKeown, Melancholy Order: Asian Migration and the Globalization of Borders (New York: Columbia University Press, 2008): 8-9.

10 L. Benton, Law and Colonial Cultures: Legal Regimes in World History 1400-1900 (New York: Cambridge University Press, 2001): 5-6, 243-4.

11 J. Onley, "Indian Communities in the Persian Gulf, c. 1500-1947." In The Persian Gulf in Modern Times: People, Ports, and History, ed. L.G. Potter (New York: Palgrave Macmillan, 2014): 231-66. 
difficulties in the 1930s. ${ }^{12}$ They often moved within and across jurisdictions, ${ }^{13}$ shrewdly appealing to British, Qajar, and Islamic authorities as it suited their interests. Extraterritoriality, nonetheless, proved a way for the British to exercise imperial power over Indians beyond the Raj. British officials seized Indian property and deported Indian subjects from Iran, especially in cases when Indians embarrassed the British vis-à-vis the Persians or when Indians appealed to local authorities to escape British law. ${ }^{14}$ Britain's legal imperialism in Persia was directed at not only Iranians but also Indians. Indeed, extraterritoriality, which in its liberal idiom was positioned as a bulwark against Asian despotism, also functioned as an instrument of the British Empire's autocratic authority.

Extraterritoriality was inextricable from nationality. The importance of early Pahlavi legal reforms for the abolition of extraterritoriality in 1928 has long been clear, ${ }^{15}$ but the role of nationality law in this process has gone largely unexplored. Nor has it received much attention in recent and important scholarship on Iranian nationalism and state-building. ${ }^{16}$ Nationality here is

12 S. Bose, A Hundred Horizons: The Indian Ocean in the Age of Global Empire (Cambridge: Harvard University Press, 2006): 72-97.

13 For significance of intermediaries in "jurisdictional politics," see Benton, Law and Colonial Cultures: 10; see also F.A. Bishara, Sea of Debt: Law and Economic Life in the Western Indian Ocean, 1780-1950 (Cambridge: Cambridge University Press, 2017): 117-24. For an account of jurisdictional politics, extraterritoriality, and nationality in the French protectorate of Tunisia, see M.D. Lewis, "Geographies of Power: The Tunisian Civil Order, Jurisdictional Politics, and Imperial Rivalry in the Mediterranean, 1881-1935." The Journal of Modern History 80/4 (2008): 790-831.

14 Similar treatment was meted out to allegedly "bad subjects" in Egypt, see W. Hanley, Identifying with Nationality: Europeans, Ottomans, and Egyptians in Alexandria (New York: Columbia University Press, 2017): 217-35.

15 A.K. Matine-Daftary, La suppression des capitulations en Perse: l'ancien régime et le statut actuel des étrangers dans l'Empire du "Lion et Soleil." (Paris: Les presses universitaires de France, 1930)—special thanks to Ali Gheissari for making this book available to me; M. Zirinsky, "Riza Shah's Abolition of the Capitulations, 1927-1928." In The Making of Modern Iran: State and Society under Riza Shah, 1921-1941, ed. S. Cronin (New York: Routledge, 2003): 81-98; W. Floor, "Judicial and Legal Systems v. Judicial System in the 2oth Century." Encyclopaedia Iranica Online (2009/2020) (http://dx.doi.org/10.1163/2330-4804_ EIRO_COM_11032); H.Zandiyah, Tahawwul-inizam-iqaza'i-yi Irandardawrah-yi Pahlavi-yi awwal ('asr-i Wizarat-i Adliyah-yi Ali Akbar Davar) (Qum: Pizhuhishgah-yi Hawzah wa Danishgah, 1392/2013): 203-41.

16 Kashani-Sabet discusses nationality law, see Frontier Fictions: 55. For recent, broader scholarship on nationalism and state building, see among others, A. Marashi, Nationalizing Iran: Culture, Power, and the State, 1870-1940 (Seattle: University of Washington Press, 2008); A.M. Ansari, The Politics of Nationalism in Modern Iran (Cambridge: Cambridge University Press, 2012); F. Vejdani, Making History in Iran:Education, Nationalism, and Print Culture (Stanford: Stanford University Press, 2015); and R. Zia-Ebrahimi, The Emergence of 
distinct from citizenship and nationalism in that it refers not to an individual's domestic political rights or to a sense of belonging to a national community but instead to an international legal status that allows one to claim and be claimed by a state. ${ }^{17}$ It is a relatively recent legal category. In Iran, one's nationality determined access to extraterritoriality and other capitulations, the ability to own landed property, and by the 1920s, eligibility for military conscription. Nationality laws and documentation proved a way for modern states to "embrace" their societies. ${ }^{18}$ Both Qajar and Pahlavi governments were keen to limit the number of persons claiming to be foreign nationals and to expand Iranian nationality as broadly as possible to include the Iranian diaspora in India through legislation in 1894 (Figures 2-3), ${ }^{19}$ 1929, and 1935. These statutes blended Iranian and foreign templates and pushed Iran into the conflict of laws; to this day Iran does not recognize dual nationality. Significantly, the British had accepted Iranian definitions of nationality as applying to individuals inside Iran and declined to extend extraterritoriality in such cases even before its abolition in 1928. Individuals also "grasped" nationality as a tool to advance their own material interests, without necessarily identifying with the state in nationalist terms. ${ }^{20}$ Such individual, transactional, and contingent claims to Iranian or British nationality undercut primordial notions of national identity. Nationality laws and their related documentation-passports, certificates of consular and census registration, and residency permits-were key sites where individuals encountered the state, both Iranian and British. Diplomatic correspondence and nationality legislation were in turn key sites where these states encountered one another and negotiated the contours of international law in the nineteenth and twentieth centuries.

Iranian Nationalism: Race and the Politics of Dislocation (New York: Columbia University Press, 2016).

17 Hanley, Identifying with Nationality: 5-9.

18 J. Torpey, The Invention of the Passport: Surveillance, Citizenship, and the State (New York: Cambridge University Press, 2000): 10-4.

19 Kashani-Sabet maintains this law dated from c. 1900-1 (Frontier Fictions: 55 ) citing a copy of its text in Habl al-matin, no. 28, 22 April 19o1/2 Muharram 1319:3-4. I am grateful for this citation and include this text as Figures 2-3. This edition of Habl al-matin did not, however, provide a date for the legislation. The 1894 date is confirmed by later Anglo-Iranian correspondence and by the publication of a French translation of the law in Journal du droit international privé et de la jurisprudence comparée 24 (1897): 1111-3, and an English translation in British and Foreign State Papers 1893-1894, vol. 86 (1899): 180-2. For an introduction to contemporary Iranian "citizenship," see N. Yeganeh, "Citizenship iii. In Modern Times (Qajar and Pahlavi Periods)." Encyclopaedia Iranica Online (1991/2020) (http:// dx.doi.org/10.1163/2330-4804_EIRO_COM_7738). 
Modern extraterritoriality and nationality in Iran, finally, overlaid an older Persianate world. ${ }^{21}$ Recent scholarship has stressed the persistence of the Persianate into the twentieth century, as merchants, religious figures, and scholars circulated commercial and communication networks closely linking India and Iran by steam, print, and telegraph. ${ }^{22}$ The maritime circuits connecting Bushihr, Masqat, and Bombay also spliced together the Persianate and the Indian Ocean Arena. ${ }^{23}$ Merchants and migrants navigated this "Persianate bazaar" 24 as well as the extraterritoriality and nationality regimes by which modern states sought to regulate it. In this context, Iranian nationality law proved both expansive and exclusive. Seeking to counter extraterritoriality, Iran's nationality law encompassed various forms of non-territorial, prenational belonging associated with the High Persianate. ${ }^{25}$ Adopting a synthetic approach characteristic of what might be called the Late Persianate, ${ }^{26}$ this legislation fused Persian and European political and legal concepts to recognize ties binding individuals and communities in Iran and India. ${ }^{27}$ But, anxious about extraterritoriality, Qajar and Pahlavi officials also made it difficult to

21 M.G.S. Hodgson, The Venture of Islam: Conscience and History in a World Civilization, vol. 2, (Chicago: University of Chicago Press, 1974; paperback edition 1977): 293. For recent, wide-ranging discussions, see N. Green, ed., The Persianate World: The Frontiers of a Eurasian Lingua Franca (Oakland: University of California Press, 2019) and A. Amanat and A. Ashraf, ed., The Persianate World: Rethinking a Shared Sphere (Boston: Brill, 2019). See various works by N. Green including Bombay Islam: The Religious Economy of the West Indian Ocean, 1840-1915 (Cambridge: Cambridge University Press, 2011); M. Kia and A. Marashi, "Introduction: After the Persianate." Comparative Studies of South Asia, Africa, and the Middle East 36/3 (2016): 379-83; M. Kia, "Indian Friends, Iranian Selves, Persianate Modern." Comparative Studies of South Asia, Africa, and the Middle East 36/3 (2016): 398417; F. Vejdani, "Indo-Iranian Linguistic, Literary, and Religious Entanglements: Between Nationalism and Cosmopolitanism, ca. 1900-1940." Comparative Studies of South Asia, Africa, and the Middle East 36:3 (2016): 435-54; J. Cole, "Iranian Culture and South Asia, 1500-19oo." In Iran and the Surrounding World: Interactions in Culture and Cultural Politics, ed. N.R. Keddie and R. Matthee (Seattle: University of Washington Press, 2002): 30-1; M. Tavakoli-Targhi, Refashioning Iran: Orientalism, Occidentalism, and Historiography (New York: Palgrave, 2001): 9, 104-7; A. Marashi, Exile and the Nation: The Parsi Community of India and the Making of Modern Iran (Austin: University of Texas Press, 2020).

23 See F.A. Bishara, "The Diver's New Papers: Wealth, People, and Property in a Persian Gulf Bazaar," in this issue; L.G. Potter, "Society in the Persian Gulf: Before and After Oil." Occasional Paper 18 (Center for International and Regional Studies, Georgetown University in Qatar, 2017), 13-7.

24 See F.A. Bishara and N. Chatterjee, "Introduction: The Persianate Bazaar" in this issue.

25 M. Kia, Persianate Selves: Memories of Place and Origin Before Nationalism (Stanford: Stanford University Press, 2020).

26 Kia terms it "Persianate modern." See Kia, "Indian Friends, Iranian Friends, Persianate Modern."

27 For new usage of such terms, see Kashani-Sabet, Frontier Fictions: 100. 
renounce Iranian nationality and took a dim view of dual nationality-one that was shared by a considerable body of international opinion, but less so by Britain. By 1940, these policies had restrained Persianate mobility and rejected a more fluid Persianate legal order in favor of a broad, but exclusive definition of Iranian nationality. ${ }^{28}$

The two documents that frame this article highlight these dimensions of the Late Persianate. The first document, the Qajar kārguzāar's letter to the British representative in Bushihr in 1894 (Figure 1) contesting Daniels's extraterritoriality, indicates the continued centrality of Persian-language correspondence and its conventions and forms for diplomatic relations between Iran and India, even as imperialism introduced significant legal distinctions and privileges among Iranians, Indians, and Europeans. ${ }^{29}$ The second document, the first Iranian nationality law, enacted that same year (Figures 2-3), limited extraterritoriality and began a sustained Iranian engagement in the emerging field of international law that was subsuming the Persianate. That, moreover, the document here is a copy of the 1894 law published by a Persian newspaper, $\mathrm{Habl}$ al-matin, in Calcutta in $1901^{30}$ demonstrates that the editors presumed that their small readership of merchants and reformists were interested in information about the new international legal order and their place in it.

\section{$1 \quad$ Extraterritoriality}

The legal order of late Qajar Iran remained a pluralistic one. In a jurisdictional division with major significance for modern Iranian history, the shah and his officials executed royal law ('urf), and the 'ulama' implemented religious law or sharia. Europeans viewed both legal systems with suspicion, criticizing them as arbitrary, lacking in proper institutions and procedures, and uncivilized. Russia obtained extraterritoriality from Iran by the Treaty of Turkmanchay in 1828, and Britain followed in 1841. Parliament laid out Britain's extraterritorial

28 For analogous alternative paths emerging from the encounter between Indian Parsis and Iranian nationalists in this period, see Marashi, Exile and the Nation.

29 Kārguzāar to Wilson, 26 January 1894/18 Rajab 1311, FO 248/59o.

30 Habl al-matin, no. 28, 22 April 1901/2 Muharram 1319: 3-4. For more on Habl al-matin and Persian newspapers in this period, see N. Parvin, "Habl al-matin." Encyclopaedia Iranica Online (2002/2020) (http://dx.doi.org/10.1163/2330-4804_EIRO_COM_2576); N. Nabavi, "Journalism i. Qajar Period." Encyclopaedia Iranica Online (2009/2020) (http://dx.doi.org/ 10.1163/2330-4804_EIRO_COM_4061); T. Atabaki, "Constitutionalism in Iran and its Asian Interdependencies." Comparative Studies in South Asia, Africa, and the Middle East 28/1 (2008): 142-53; C.M. Amin, "The Press and Public Diplomacy in Iran, 1820-1940." Iranian Studies 48/2 (2015): 269-87; Kia, "Indian Friends, Iranian Selves." 
legal architecture in the Foreign Jurisdiction Act of 1843 and in subsequent Orders in Council for specific foreign states. ${ }^{31}$ The situation in Iran was further complicated by the fact that in 1889 , Parliament issued two mutually exclusive Orders in Council, one applying British law to inland Persia and the other applying Anglo-Indian law to the "Persian Coasts and Islands." ${ }^{32}$ Britain's and India's legal frontiers met in Iran, and an imperial legal order was superimposed on an older Persianate world. Crucially, a person's legal standing, rights, and privileges in this world were now based upon his or her nationality. Consuls appointed by the British Foreign Office and residents appointed by the Government of India supervised this system; the British official at Bushihr held both offices. In response, the Persian foreign ministry sent kārguzārāan to provincial cities to manage relations between Iranians and foreigners enjoying extraterritorial protection and their consuls. This quintessentially nineteenth-century arrangement produced considerable sub-ministerial diplomatic correspondence between kārguzāāān and consuls, as the cricket incident revealed.

About a month after Muhammad Riza's death in November 1893, Muhammad Hasan Khan Mafi Sa'd al-Mulk, the Governor of Bushihr and a member of the influential Nizam Mafi family, complained to Tehran that his efforts to obtain compensation for the boy's family had been opposed by the British consul-general and resident, J.A. Crawford, and he warned that the 'ulama' were not pleased..$^{33}$ On 12 December 1893 the kārguzār wrote Crawford, seeking an indemnity in accordance with religious law. ${ }^{34}$ The following day, Vice-Consul J.C. Gaskin interviewed Daniels, the other two players, and the residency's medical staff but did not collect statements from any Persian witnesses. Gaskin summarily concluded that there "was not sufficient evidence to justify the trial of Mr. Daniels for an offense under the Indian Penal Code." ${ }^{35}$ In forwarding this judgment to the kārguzāar, Crawford reasserted British extraterritoriality: "As a British subject at Bushire Mr Daniels is liable to and must be dealt with according to, the laws of British India." ${ }^{36}$ Daniels had, nonetheless,

$31 \quad$ Kayaoğlu, Legal Imperialism: 44-5.

32 "Order in Council providing for the Exercise of Her Majesty's Jurisdiction in Persia," 13 December 1889, and "Order in Council providing for the Exercise of Her Majesty's Jurisdiction in the Persian Coasts and Islands," 13 December 1889. In British and Foreign State Papers 1888-1889, vol. 81 (London): 805-935.

Sa'd al-Mulk telegram to Dabir al-Mulk (trans.), 11 December 1893/2 Jumada II 1311, FO 248/566.

34 Crawford to Kārguz̄ār, 18 December 1893, FO 248/567.

35 Gaskin, Report, 13 December 1893, FO 248/567.

36 Crawford to Kārguzāār, 18 December 1893, FO 248/567. 
testified that there was "no one more sorry than myself that such an accident occurred and I am willing to give any reasonable compensation to the father."37 Crawford informed the kārguzār that he believed Rs. 300 was an appropriate sum and that the father, Mashhadi Haji Sabbagh, could collect it at the British residency.

Undeterred, the kārguzār kept up the pressure, writing again to the British resident on 26 January 1894 (Figure 1). ${ }^{38}$ The document here is a copy made by a residency secretary, Ahmad Munshi, which was forwarded, together with an English translation (Appendix), to the British minister in Tehran, Sir Frank Lascelles, the following month - the original likely being retained at Bushihr. ${ }^{39}$ Duplicates were probably sent to India. The kārguzāar's letter took the form of a reply $(j a w \bar{a} b)^{40}$ to Crawford's letter (murāsalah), no. 440, dated 9 Jumada II 1311/18 December 1893. He plainly laid out the facts as he understood them: Daniels and his colleagues had taken insufficient precautions while playing cricket, had accidentally killed Muhammad Riza, and "must, in accordance with shari'a and the law of this country (qānūn-i in mamlakat), give satisfaction to the victim's father" at the kārguzāar's office. ${ }^{41}$ In linking qānūn and mamlakat here, moreover, the kārguzār expressed a territorially expansive view of "country," or domain, as defined by a kind of legal uniformity that was tied not only to the Qajar dynasty but also to the Iranian state. ${ }^{42}$ Islamic law too, he believed, was relevant to the case, especially as regards compensation (diyah). He did not explicitly refer to British extraterritoriality and tacitly framed the incident as a civil matter rather than a criminal one to void Gaskin's judgment and achieve a settlement in court. He doubted whether Mashhadi Haji Sabbagh would accept only Rs. 300, requested Daniels to appear on 28 January, and closed by expressing his hopes for a quick resolution of this tragic case.

Throughout his letter, the kārguzāâr addressed the British resident as a friend

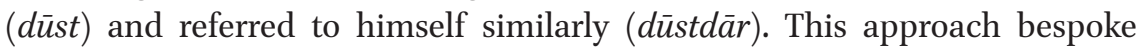
diplomatic equality and good relations and conveyed a sense of obligation characteristic of the "ethico-didactic" quality of Persianate literary form (adab)

37 Statement by Daniels to Gaskin, 13 December 1893, FO 248/567.

38 Kārguzāar to Wilson, 26 January 1894/18 Rajab 1311, FO 248/59o.

39 Wilson to Lascelles, 12 February 1894, FO 248/59o.

40 In Persian letter-writing (insh $\vec{a}$ ), which was fully "bureaucratized" under the Safavids, each kind of letter had its own distinct form of jawāb. See C. Mitchell, "Safavid Imperial Tarassul and the Persian Inshä’ Tradition." Studia Iranica 26 (1997): 184.

41 My translation here. For residency translation, see Appendix.

42 For this shift in the meaning of qānūn, see G. Burak, "Between the Kānūn of Qāytbāy and Ottoman Yasaq: A Note on the Ottomans' Dynastic Law." Journal of Islamic Studies 26/1 (2015): 23. For multiple and shifting meanings of mamlakat, see Kia, Persianate Selves: 36-40 and Tavakoli-Targhi, Refashioning Iran: 114. 


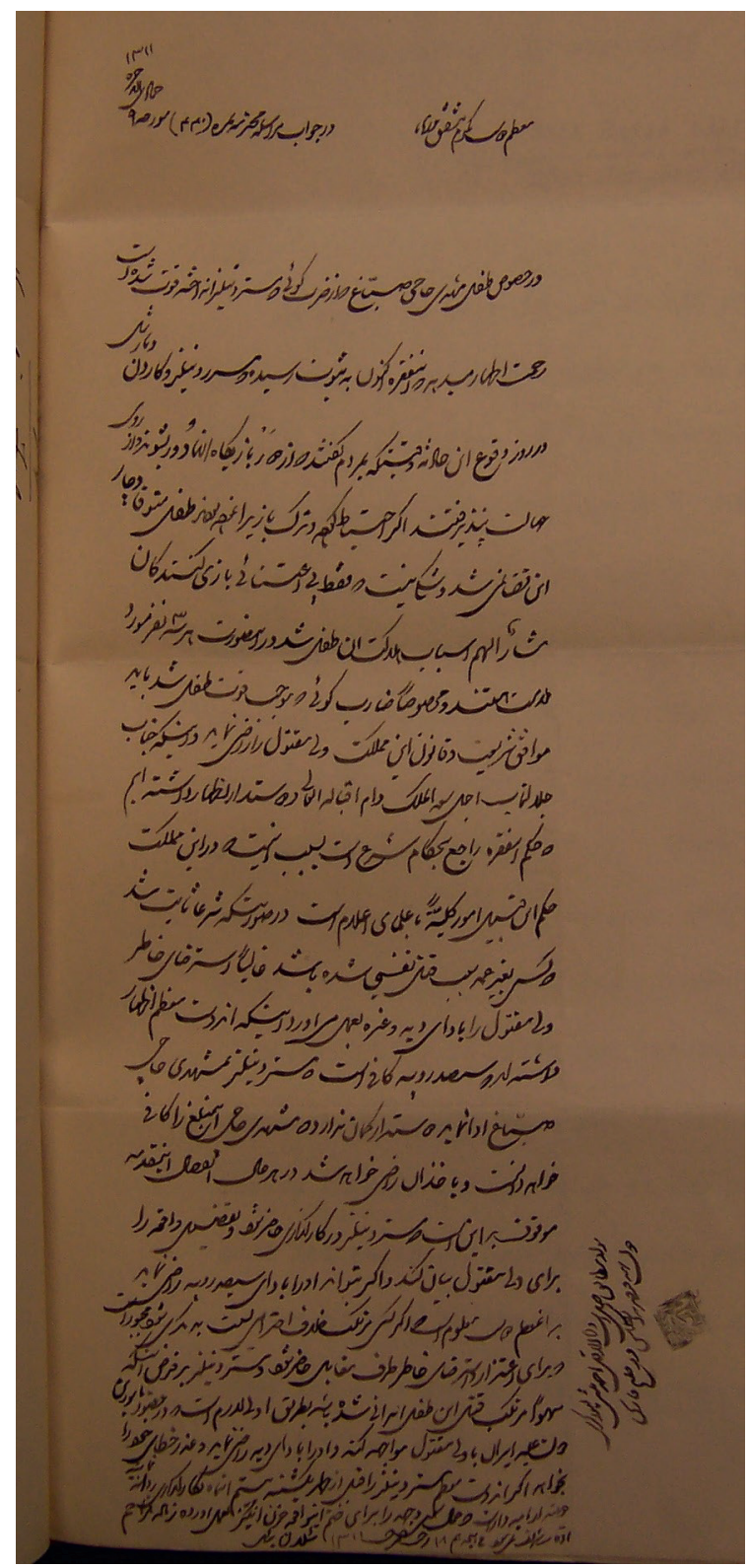

FIGURE 1 Kārguz̄ār to Wilson, 26 January 1894/18 Rajab 1311, FO 248/59O WITH PERMISSION, UK NATIONAL ARCHIVES 
and correspondence (insh $\left.\bar{a}^{3}\right){ }^{43}$ If the British resident could only understand the case clearly, he would certainly meet the kārguzār's friendly request. A new consul-general, F.A. Wilson, who had replaced Crawford, received this letter but rejected the kārguzāar's proposal as a recognition of Iranian jurisdiction and would not permit Daniels to come before the Persian authorities. ${ }^{44}$ In the residency's English translation of the kārguzāā's letter, dūst and dūstdār were rendered "you" and "I" - pronouns that did not convey fully the kārguzār's meaning. On 2 February, the kārguzār forwarded Wilson a copy of a letter from the imām-i jum'ah to Sa'd al-Mulk, warning the governor that failure to resolve the case might provoke popular unrest in Bushihr. ${ }^{45}$ Wilson took exception to what he perceived as a threat and referred the matter to Tehran. ${ }^{46}$ An overture of Persianate friendship had foundered on British notions of diplomatic civility. The prime minister (șadr-i azam), Mirza Ali Asghar Khan Amin al-Sultan, quickly agreed with the legation, and instructions were sent to Wilson and Sa'd al-Mulk to reach a private settlement along British lines, which presumably occurred as the correspondence ends there. ${ }^{47}$

At first glance this case was a clear example of extraterritoriality. The British government shielded Daniels from Persian prosecution. For Wilson, the imām-i jum'ah's letter was evidence of the deficiencies of Islamic law. ${ }^{48}$ That said, it is significant that the governor, kārguzāar, and imām-i jum'ah all challenged British jurisdiction. ${ }^{49}$ The extraterritoriality regime, which had been established in Iran for over half a century, met with considerable Iranian resistance. Interestingly, both sides acknowledged the desirability of compensation, but they disagreed pointedly as to under which authority such compensation was to be made. Local opposition then obliged the consul-general to forward this unfortunate but relatively minor matter to Tehran.

The controversy surrounding Muhammad Riza's death also illustrates ways in which extraterritoriality impacted relations between the Qajar state and the Shici 'ulama'. Although the 'ulama' could withhold legitimacy from the Qajars

43 Kia, "Indian Friends, Iranian Selves": 404; see also, J. Paul, "Insh $\bar{a}$ Collections as a Source on Iranian History." In Proceedings of the Second European Conference of Iranian Studies, ed. B.G. Fragner et al. (Rome: Istituto Italiano Per Il Medio Ed Estremo Oriente, 1995): 535-5o; E.J. Flatt, "Practicing Friendship: Epistolary Constructions of Social Intimacy in the Bahmani Sultanate." Studies in History 33/1 (2017): 61-81; Mitchell, "Safavid Imperial Tarassul."

44 Wilson to Kārguzāār, 2 February 1894, FO 248/590.

45 Imām-i jum'cah to Sa'd al-Mulk (trans.), n.d., FO 248/590.

46 Wilson to Karguzar, February 7, 1894, FO 248/59o.

47 Legation minutes, 19, 22, and 23 February, 1894, FO 248/567.

48 Wilson to Lascelles, 12 February 1894, FO 248/59o.

49 See also Gilbar, "Resistance to Economic Penetration": 17. 
and did frequently oppose them, most notably during the Tobacco Protests and the Constitutional Revolution, they also depended on the state for the protection of Islam and the maintenance of the social order. ${ }^{50}$ Both dynamics were at work in this case. On the one hand, the imām-i jum'ah, although appointed by the state, demanded that the governor not allow foreigners to kill Iranian Muslims with impunity. On the other, his appeal to Sa'd al-Mulk was a recognition that relations with foreign governments were the prerogative of the state, not the 'ulama'. And yet, Sa'd al-Mulk and the kārguzār enlisted the 'ulama' against the British while also seeking to enhance the legitimacy of state institutions by compelling Daniels to reach a settlement at the kārguzāā's court, not the British consulate, or for that matter the shari'a court. True, they failed but not before involving Amin al-Sultan.

And then there is Daniels himself. In the end, his willingness to pay Mashhadi Haji Sabbagh was essential to concluding the affair. He was saddened by Muhammad Riza's death and eager to make amends in whatever way he could. He also certainly realized that failure to pay would render his personal position in Bushihr untenable. His government could defend him from Persian prosecution, but it could not protect him from social ostracism, or perhaps, as the imām-i jum'ah had implied, worse. While his status as a foreign subject placed him in a different legal domain, he remained a member of a community and was subject to its social and cultural expectations. Not paying was not really an option. Daniels, furthermore, could not expect much more support from British officials. As Crawford explained to the kārguzār, Daniels was "only an Eurasian clerk drawing Rs 250 per mensum." ${ }^{51}$ Crawford's casual contempt for Daniels's Indian parentage and occupation demonstrates that British exterritoriality in Iran was inseparable from its colonial context.

Indians living in Qajar Iran regularly sought British intervention with Persian officials - as had some Iranians going back to the Safavid period. Although they were British subjects, Indians often straddled jurisdictional lines between British, Indian, and Iranian law. On 8 April 1894, the "Hindu community resident in Kirman (jamā'at-i Hindū-yi sākin-i Kirmānn)" petitioned Surgeon Major G.W. Brazier Creagh, who was touring the area with Percy Sykes, for recovery of debts from local Iranians. ${ }^{52}$ These Indians were members of an expansive Shikarpuri commercial network stretching from Sind to

50 A. Amanat, Iran: A Modern History (New Haven: Yale University Press, 2017): 25-6, 202-3.

$5^{1}$ Crawford to Kārguzār, 18 December 1893, FO 248/567.

$5^{2}$ Hindus of Kirman to Wilson, 8 April 1894/1 Shawwal 1311, FO 248/591. 
Iran, Afghanistan, Russian Central Asia, and Sinkiang. ${ }^{53}$ They enjoyed a leading position in Kirman's international trade and played an important role in integrating the region into the growing global economy. ${ }^{54}$ Their petition made an interesting journey. Composed in Persian, it was addressed to the consulgeneral in Bushihr. Upon reaching Karachi, Brazier Creagh duly mailed it to Wilson in Bushihr, who sent a copy and an English translation to the legation in Tehran. ${ }^{55}$

The Shikarpuris in Kirman were Persianate foreigners and imperial subjects. When Edward Stack of the Bengal Civil Service visited Kirman in April 1881, he reported that this community numbered forty people headed by two bankers. They occupied a caravanserai owned by the qazi, dressed in a Persian style, and were permitted to perform Hindu rituals. It is unclear whether a Shikarpuri drafted the 1894 petition himself or engaged an Iranian secretary to do so, but the choice of Persian suggests the petitioners were more comfortable in this language than in English. As Claude Markovits has observed, "Shikarpuri Hindus lived in a cultural world which was Persianized, even if few of them knew High Persian. Their commercial terminology was Persian and may have been originally imported from that country."56 Some of them evidently had facility in colloquial Persian. Stack described an incident in which the Shikarpuris insulted a local official "fearlessly in choice Persian slang" after he charged an extortionate fee for accompanying a Hindu funeral procession. ${ }^{57}$ Stack, nonetheless, considered these Indians to be racially inferior not only to the British but also to the Persians: "In their Persian dress and tall felt hats they presented a miserable contrast to the genuine Persian. I never was more forcibly reminded of the physical inferiority of the Hindoo race. They looked like withered black apes." 58 Two decades later, Sykes took exception to Stack's language, affirming that this community were enterprising merchants, but he still

53 C. Markovitz, The Global World of Indian Merchants, 1750-1947: Traders of Sind from Bukhara to Panama (Cambridge: Cambridge University Press, 2000). For an account with interesting parallels, see HW. Warner, "The Kabuliwalas: Afghan moneylending and the credit cosmopolis of British India, c. 1880-1947." Indian Economic and Social History Review 57/2 (2020): 171-98.

54 J. Gustafson, Kirman and the Qajar Empire: Local Dimensions of Modernity in Iran, 1794-1914 (New York: Routledge, 2016): 94-101.

55 Brazier Creagh to Wilson, 14 May 1894, FO 248/591; Wilson to Conyngham Greene, 8 June 1894, FO 248/591.

56 Markovits, Global World of Indian Merchants: 103-4.

57 E. Stack, Six Months in Persia, vol. 1 (London: Sampson Low, Marston, Searle \& Rivington, 1882): 214 .

$5^{8} \quad$ Stack, Six Months, vol. 1: 213 . 
felt obliged to observe that "as to their appearance, it is not prepossessing."59 Although all British subjects could claim extraterritoriality in Iran, all British subjects were not equal in the eyes of British officers.

In April 1894, the Shikarpuris requested British assistance with debts in Kirman and Bahramabad, complaining that their debtors bribed local authorities to evade repayment. ${ }^{60}$ As was typical of bankruptcy cases in Qajar Iran, efforts to reach speedy settlements had failed. ${ }^{61}$ Petitioning was the main way for Iranians to seek redress of grievances. It was integral to the ideology of the Qajar monarchy and the shah's critical role in ensuring the circle of justice. ${ }^{62}$ It was also common political practice in Britain and South Asia as well. ${ }^{63}$ The Shikarpuris' petition, however, did not receive a favorable reception from the British legation's second Oriental Secretary, Mirza Hasan 'Ali Khan Nawwab, in Tehran. The Nawwabs were themselves a Perso-Indian family, several of whom held British diplomatic posts in Qajar Iran. Hasan 'Ali Khan had been educated in Bombay and served in Shiraz, Afghanistan, and Mashhad before taking up this appointment in Tehran. ${ }^{64}$ Dismissing the petitioners, he explained that "certain individuals of the Hindoos are usurers and they lend out money on nearly 50 to 100 per cent." ${ }^{65}$ British authorities stereotyped the Shikarpuris as parasitic moneylenders in Sind too. ${ }^{66}$ Hasan 'Ali Khan had investigated similar cases in Hashtadan, near Kirman. He alleged that the claims were sometimes nearly twenty years old and that the loans, often carrying $50 \%$ compound interest, were frequently sold from one lender to another. When these creditors, furthermore, learned that the legation would only seek to collect $12 \%$ interest, they dropped their cases with British officials, electing instead to negotiate privately with their Persian debtors.

Hasan 'Ali Khan noted that Shikarpuri merchants at Khwaf in Khurasan had also recently "pestered" the legation on this account. Colonel C.E. Yate alleged their lending practices caused considerable economic dislocation and popular

59 P. Sykes, Ten Thousand Miles in Persia or Eight Years in Iran (London: John Murray, 1902): 198-9.

6o Hindus of Kirman to Wilson, 8 April 1894/1 Shawwal 1311, FO 248/591.

61 W.M. Floor, "Bankruptcy in Qajar Iran." Zeitschrift der Deutschen Morgenländischen Gesellschaft 127/1 (1977): 61-76.

62 I. Schneider, The Petitioning System in Iran: State, Society and Power Relations in the late 19th Century (Wiesbaden: Harrassowitz, 2006): 30-3, 102-5.

63 For the latter see, R. De and R. Travers, "Petitioning and Political Cultures in South Asia: Introduction.” Modern Asian Studies 53/1 (2019): 1-20.

64 Picot, "Persia. Biographical Notices of Members of the Royal Family, Notables, Merchants and the Clergy," December 1897, Fo 6o/595.

65 Minute by Mirza Hasan 'Ali Khan Nawwab, 28 June 1894, FO 248/591.

66 Markovits, Global World of Indian Merchants: 50. 
discontent. He observed that these Indians declined British extraterritoriality in favor of Persian mediation. They "know that by appealing to the Consulate for the settlement of their cases this exorbitant rate of interest would not be allowed, and although by Consular rules, if they wish British protection, they are bound to register themselves as British subjects every year on a fee of half a crown; they steadily refrain from doing this, preferring to trust to the support of the Persian authorities." ${ }^{\prime 6}$ Shikarpuri merchants at Hashtadan and Khwaf alertly exploited the legal pluralism of the Late Persianate world. As such, they straddled the legal line that extraterritoriality was meant to clarify. Such "forum shopping" 68 was clever, but it did not endear its practitioners to the British or the Iranians.

Indian merchants could also get themselves into significant debt in Iran, as the case of one Goverdhandas Valji reveals. Goverdhandas (as he is most commonly referred to in British sources) was a British subject, a Hindu, and a merchant who served as the Iranian customs master in Bandar-i Lingah on the Persian Gulf for much of the 188os and 189os. Customs houses were central nodes connecting trade, information, finance, and the state in this maritime world.$^{69}$ Goverdhandas farmed customs, advancing money to the local authorities and profiting from the customs dues he collected. ${ }^{70}$ After Tehran hired Belgian officers to establish a centralized customs administration in 1900, Goverdhandas was relegated to the status of a customs cashier-a financial blow. By 1905 he was in trouble. Owing some Rs. 70,0oo to Persian merchants, he wrote them checks on a Bombay bank and left Bandar-i Lingah. The checks bounced. At Iran's request, the British resident at Bushihr, Major Percy Cox, secured Goverdhandas's arrest in Masqat, returned him to Bandar-i Lingah, and detained him at the house of the British agent, Aqa Badr. A group of Lari creditors surrounded Aqa Badr's house, claiming to take sanctuary (bast) under the British flag there, and demanded the surrender of the debtor and his assets. ${ }^{71}$ The British prevailed on the Governor of the Gulf Ports, Mirza Ahmad Khan Darya Baygi, to sail from Bushihr and disperse the demonstrators.

67 Yate, Diary, 3-8 April 1894, Fo 6o/563, in Foreign Office Documents on Persia 1899-1913, microfilm University of Chicago (London, 1970s): reel 2.

68 M. Sharafi, "The Marital Patchwork of Colonial South Asia: Forum Shopping from Britain to Baroda." Law and History Review 28/4 (November 2010): 979-1009.

69 Bishara, Sea of Debt: 50-5.

70 Cox, "Memorandum regarding a recent case at Lingah arising from the defalcations of a Hindu British Subject—Gordhandass," 25 June 1905, FO 248/843.

71 The long-established custom of bast involved taking sanctuary to avoid prosecution and/ or voice protest in certain religious and royal sites and later foreign embassies and consulates. See, J. Calmard, "Bast." Encyclopaedia Iranica Online (1988/2020) (http://dx.doi. org/10.1163/2330-4804_EIRO_COM_6726). 
The British consul at Bandar-i 'Abbas then held long sessions reviewing Goverdhandas' accounts with his creditors. He speculated that Goverdhandas had attempted "in collusion with the two native banking firms in Bombay" to perpetrate "a fraudulent bankruptcy."72 British authorities in the Persian Gulf could dispose of Goverdhandas' property in Bandar-i Lingah, but the Indian courts would have to pursue the matter of the Bombay banks.

Goverdhandas, meanwhile, attempted to collect debts owed him. He had claims against the Iranian government dating back to 1898-99, when Shaykh Muhammad ibn Khalifa crossed from the Arab coast and briefly seized control of Bandar-i Lingah. ${ }^{73}$ Goverdhandas had already purchased the customs farm for Rs. 20,00o that year, but Shaykh Muhammad obliged him to pay an additional Rs. 10,00o. In March 1899, Darya Baygi ejected Shaykh Muhammad, and on $18 \mathrm{March}$, he prevented an Indian steamer from landing its cargo, alleging that the quarantine sheds had been damaged during the assault on the port. The cargo was only landed on 21 March. This date, Nowruz, was significant because Goverdhandas' customs contract had expired the previous day, allowing Darya Baygi to pocket Rs. 3,500 in duties on the cargo. Goverdhandas alleged that Darya Baygi had caused the delay to deprive him of these monies. Interestingly, one report of this affair was provided to Cox in 1906 by an employee of Messrs. Grey, Paul \& Co., named James W. Daniels, who had been in Bandar-i Lingah in $1899 .{ }^{74}$ This man was very probably the same who had accidentally killed Muhammad Riza in 1893. Evidently Daniels had been able to make a life in the Persian Gulf. Goverdhandas's tenure there, however, was coming to a close. In March 19o6, Cox declared that Goverdhandas had proved himself a "thorough rascal" who could not possibly repay his sizeable debts. ${ }^{75}$ In August, Cox deported him from Iran to Karachi. ${ }^{76}$ For Goverdhandas, extraterritoriality was a sword that cut two ways. He had enjoyed some of the benefits of British protection, but at the end of the day he found himself in India, cut off from the networks and livelihood he had cultivated for thirty years in Iran.

British extraterritoriality in Iran could lead to a fate worse than deportation. In March 1907, the British consul in Sistan, Major R.L. Kennion, convicted an Indian named Amir Shah of robbery and sentenced him to a year's hard labor in India and a $£_{15}$ fine..$^{77}$ Kennion also alleged that one of the witnesses in the case, Munshi 'Umar Din, a consulate clerk from Peshawar, had perjured

72 Shakespear to Cox, 11 July 1905, FO 248/843.

73 Cox to Legation, 31 March 1906, FO 248/875.

74 Statement by Daniels, 24 March 1906, Fo 248/875.

75 Cox to Legation, 31 March 19o6, FO 248/875.

76 Cox to Legation, 4 September 19o6, FO 248/876.

77 Kennion, Judgment of Amir Shah, 3 April 1907, FO 248/9o9. 
himself. ${ }^{78}$ Fearing British prosecution, 'Umar Din and his wife took bast at the house of a prominent mujtahid, Mullah Mahdi. Kennion claimed that the 'ulama' were much interested in the case: "the successful protection of a British subject through the principle of 'bast'-would of course add enormously to their prestige."79 Iranian authorities, nevertheless, surrendered 'Umar Din to the British. He explained that he fled to Mullah Mahdi's protection because he objected to the ways in which British officers had questioned his wife and searched his property. Kennion had indeed disparaged this woman as a "prostitute" in his official consulate diary. ${ }^{80}$ Consequently, "Umar Din argued that the consular court was biased against him. Kennion rejected this defense as "absolutely baseless and frivolous" and sentenced 'Umar Din to three months' incarceration in Bombay and a $£_{15}$ fine. ${ }^{81} \mathrm{He}$ acknowledged that this maximal punishment was necessary because the "mode adopted by the accused of avoiding lawful apprehension by what amounts to an appeal to racial and religious feeling is in the highest degree objectionable and even dangerous to public order." That an Indian consular employee in Iran would seek Islamic protection from British justice was unacceptable to Kennion; it is no wonder then, 'Umar Din received such a stiff sentence.

Extraterritoriality raised legally significant questions about nationality, questions that were complicated by the longstanding Persianate connections between Iran and India and by the impact of nineteenth-century trade, travel, and communications. Status as a British subject had clear advantages under the extraterritoriality regime, and both the Qajars and the Pahlavis were keen to limit the number of persons claiming these privileges by defining Persian nationality as widely as possible. Iranian officials, moreover, understood population to be a key indicator of modern power and were anxious that emigration was weakening a state that had already seen its territories diminish throughout the century. With roughly 10 million inhabitants, Iran was sparsely populated. Persians petitioning Qajar authorities understood these insecurities when they threatened emigration should their grievances go unheard. ${ }^{82}$

\footnotetext{
78 Kennion, Judgment of 'Umar Din, 3 April 1907, Fo 248/909.

79 Sistan Diary, week ending 30 March 1907, FO 248/909.

8o Sistan Diary, week ending 23 March 1907, FO 248/909.

81 Kennion, Judgment of 'Umar Din, 3 April 1907, FO 248/9o9.

82 Kashani-Sabet, Frontier Fictions: 53-4, 83 .
} 
Iranian governments of various stripes asserted Persian nationality to combat extraterritoriality and to claim subjects living in India and elsewhere.

Iran did not recognize British nationality for persons born in India of Persian descent. In the common law tradition, British subjecthood applied to all persons born in the "dominions and allegiance" of the British crown. ${ }^{83}$ The Iranian foreign ministry rejected this principle in January 1876 in the case of a merchant named Aqa Mahdi, who had been born in India to Persian parents. Mirza Husayn Khan Mushir al-Dawlah, the foreign minister, agreed to allow Aqa Mahdi to continue to pay the preferential $5 \%$ customs duty as a courtesy to the British minister but insisted that such persons were Persian subjects and that he would not accept British diplomatic protection on their behalf. ${ }^{84}$ The foreign ministry thus maintained that Persian nationality was a function of descent, or in European terms, jus sanguinis, as distinct from birthplace, jus soli, which was maintained by Britain. In modern history, "countries of emigration" have tended to embrace jus sanguinis and "countries of immigration," jus soli. ${ }^{85}$ Many nationality laws mix both principles to varying degrees. Iran would adopt both strategies because of its historical ties with India and the imperial strains of extraterritoriality. British officials accepted Iran's assertion of jus sanguinis. In response to a query from the Persian consul-general in 1884, the Government of Bombay acknowledged that it issued certificates of naturalization to Persians "domiciled" in India and recognized persons born in India of Persian parents as British subjects. ${ }^{86}$ It confirmed, however, that in accordance with Tehran's views, British officials treated both classes of persons as Persian subjects while they were in Iran.

In August 1894, Nasir al-Din Shah's government issued Iran's first modern nationality law. Translations were published in French in 1896 and 1897 and in English in 1899. ${ }^{87} \mathrm{Habl} \mathrm{al-matin}$ followed with a Persian copy in 1901 (Figures 2-3) under the title "Qanun-namah-yi taba'iyat-i dawlat-i 'aliyah-yi Iran." 88 It included key elements of this international, legal genre: enumerated articles, inclusionary and exclusionary language based on jus soli and jus

83 L. Fransman et al., British Nationality Law (Haywards Heath, West Sussex: Bloomsbury Professional, 3rd edition, 2011): 130.

84 Mushir al-Dawlah to Thomson (trans.), 19 January 1876, IOR L/P\&S/18/C16: 2 (https:// www.qdl.qa/en/archive/81055/vdc_100000000833.0x00004e).

85 P. Weil, How to be French: Nationality in the Making since 1789 (Durham: Duke University Press, 2008): 191; see also, Torpey, History of the Passport: 72.

86 Government of Bombay to Persian Consul-General, 4 October 1884, IOR L/E/7/1346.

87 Journal du droit international privé et de la jurisprudence comparée 24 (1897): 1111-3; British and Foreign State Papers 1893-1894, vol. 86 (1899): 180-2.

88 Habl al-matin, no. 28, 22 April 1901/2 Muharram 1319: 3-4. This copy of the law uses both taba'iyat and täbicinat for nationality — the latter will be used below. Kia has also cited 

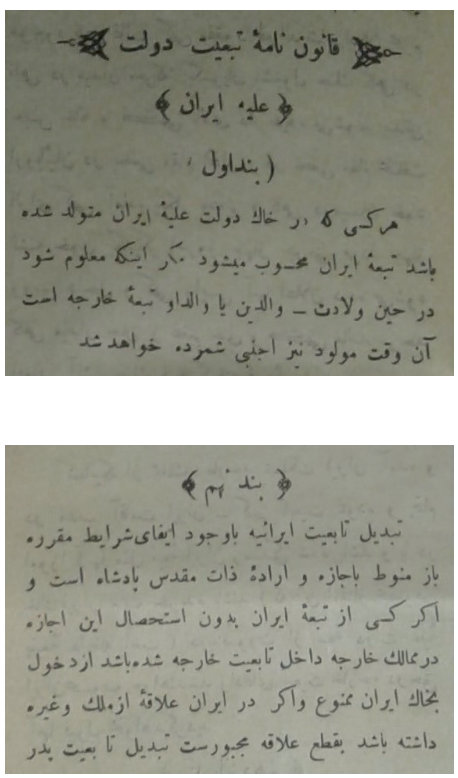

\section{FIGURE 2}

Iranian Nationality Law, 1894, Article 1, Habl al-matin, no. 28, 22 April 1901/2 Muharram 1319: 3 PRINCETON UNIVERSITY LIBRARY

\section{FIGURE 3}

Iranian Nationality Law, 1894, Article 9, Habl al-matin, no. 28, 22 April 1901/2 Muharram 1319: 3

PRINCETON UNIVERSITY LIBRARY

sanguinis, and provisions regarding naturalization, nationality renunciation, marriage, property, and military service. ${ }^{89}$ Article 1 claimed as Persian subjects all persons born in Iran-i.e. jus soli-except those born to foreign parents. Individuals in the latter category could become Persian nationals on reaching adulthood. This law has been cited as evidence of the growing significance of territorial nationalism and "citizenship" in Iran and as an effort to link the individual's allegiance not only to the sovereign but also to the "land." 90 This argument needs some qualification. The word, täbiciyat, used in this law can today refer to citizenship, but it is better translated in this historical context as nationality, ${ }^{91}$ especially given its meanings of "dependence, subjection, following." ${ }^{2}$ The Iranians likely borrowed this usage of tābi'ìyat and several other provisions from the Ottoman nationality law of 1869 (Tabiciyet-i Osmaniye

Habl al-matin as a space for "ethico-didactic" reformist letter-writing and "Persianate friendship"; see "Indian Friends, Iranian Selves."

89 For qānūn and international law, see Burak, "Between the Kānūn of Qāytbāy and Ottoman Yasaq": 23.

$90 \quad$ Kashani-Sabet, Frontier Fictions: 55.

91 Hanley, Identifying with Nationality: 5-9, 56-6o.

92 S. Hayyim, New-Persian English Dictionary (https://dsal.uchicago.edu/dictionaries/ hayyim/). I also consulted various online/app versions of 'Ali Akbar Dihkhuda's Lughatnamah-yi Dihkuda. 
kanunnamesi) ${ }^{93}$ Following the Napoleonic Code of 1804 and the French law of $1851,{ }^{94}$ the Ottomans prioritized jus sanguinis in 1869 , whereas the Iranians in 1894 privileged jus soli, perhaps following the new French nationality law of $1889 .{ }^{95}$ The latter legislation "created the republican use of jus soli" by linking "socialization and nationality"96 But Iran's nationality law harkened back to an Old-Regime conception of jus soli that linked birth, soil, and allegiance to the king - precisely also the principle undergirding British nationality law. Critically, Article 9 stipulated that expatriate Persians adopting a foreign nationality first needed the shah's permission, failing which they would be denied entry into Iran and obliged to sell their property (milk) there. Royal sovereignty remained central to defining Persian nationality. Even as it entered an international legal order, qānūn remained firmly tied to its dynastic origins.

Although the shah's government invoked jus soli in 1894, it continued, as it had since the 1870 , to apply jus sanguinis to people born abroad to Iranian fathers, arguing such persons had not obtained royal permission to renounce Iranian nationality. This situation provoked Harold Nicolson, a legation counsellor, to remark playfully as late as 1926 that the Iranian position "if pushed back to its logical conclusion, would lead to the view that a considerable portion of the world's inhabitants, perhaps the whole of the Aryan stock, are at present Persian subjects." ${ }^{97}$ Race would of course help fracture the Persianate, but at the turn of the twentieth century, the Qajar combination of jus soli, jus sanguinis, and involuntary subjection to royal authority made Iranian nationality a broadly expansive category. But in punishing the failure to obtain royal authorization to adopt a foreign nationality, Article 9 of the 1894 law also laid the groundwork for a definition of Iranian nationality that discouraged Iranians from holding dual (or multiple) nationalities. The new Iranian embrace was a wide but jealous one.

Persian consuls pursued these nationality policies in India. In January 19oo, the consul-general in Bombay, Hajj Muhammad Mirza Kashif al-Saltanah, who

93 I thank Annie Greene for alerting me to this Ottoman legislation. For title of Ottoman nationality law of 1869, see K.M. Kern, Imperial Citizen: Marriage and Citizenship in the Ottoman Frontier Provinces of Iraq (Syracuse: Syracuse University Press, 2011): 16, and for translation, see 157-58.

94 Kern, Imperial Citizen: 91.

95 As mentioned above, nationality laws frequently mix jus sanguinis and jus soli. Article 2 of the Ottoman law incorporated jus soli by allowing the children born in the empire to foreigners to claim Ottoman nationality within three years of reaching adulthood. Article 1 of the Iranian law accepted jus sanguinis by exempting from Iranian nationality the children born in Iran to foreigners.

96 Weil, How to be French: 52-3. (emphases original)

97 Nicolson to Chamberlain, 4 November 1926, IOR L/E/7/1346. 
became famous for bringing tea cultivation from India to Iran, ${ }^{98}$ lamented that the many Persians emigrating to India would shortly leave "Iran destitute of inhabitants and subjects (İrān khālè az sakanah wa ra'̄yat)." ${ }^{\prime 99} \mathrm{He}$ connected this issue to the abuse of extraterritoriality, claiming hyperbolically that a third of Iran's population who had never even left their own towns enjoyed Russian or British protection. His solution was new legislation barring Iranians from abandoning their "original nationality (tābicíyat-i aṣlü)." It is entirely possible that Iranian consuls in India provided Habl al-matin with a copy of the 1894 nationality law for publication in April $1901 .{ }^{100}$ This information was clearly significant to individuals seeking to establish their nationality for purposes of travel, residency, and protection. That August, Mirza 'Ali Muhammad Khan Muwaqqar al-Dawlah, consul-general at Bombay, requested an identity document/passport (tazkirah) for Nawwab 'Imad Nawaz Jang.101 Iran had begun issuing and requiring this tazkirah the year before. ${ }^{102}$ Interestingly, tazkirah had hitherto referred to (auto)-biography and memoir, a genre which has recently been cited as evidence for the multiplicity of linkages between individuals and communities across the High Persianate. ${ }^{103}$ In applying for his tazkirah, Nawwab 'Imad Nawaz Jang relayed his history. His ancestors were Iranians, and he had served as a financial administrator for the Nizam of Hyderabad. He married the daughter of an English consular officer stationed at Baghdad, and she in turn converted to Islam. Nawwab Imad Nawaz Jang now desired to settle in Iran on his Hyderabadi pension. In applying for a tazkirah, he stressed that he had never surrendered his Iranian nationality, a claim that demonstrated an awareness of the 1894 law. In January 1903, Mirza Mahmud Khan Mufakhkham al-Sultan, the newly appointed consul-general at Calcutta, received a very warm welcome from the city's Armenian community, whose ancestors, he explained, hailed from (New) Julfa. ${ }^{104}$ This community had in

98 M. Bamdad, Sharh-i hal-irijal-i Iran dar qarn-i 12 wa 13 wa 14 hijri, vol. 3 (Tehran: Intisharat-i Zawwar, 1968/1347): 273-4.

99 Kashif al-Saltanah to Ministry of Foreign Affairs, 1 January 1900/28 Shaban 1317. In Asnadi az rawabit-i Iran wa Hind dar dawrah-yi Muzaffar al-Din Shah Qajar, ed. A. Jalali Farahani (Tehran: Wizarat-i Umur-i Kharijah, Mu’assasah-yi Chap wa Intisharat, 1997/1376): 70.

100 Habl al-matin, no. 28, 22 April 19o1/2 Muharram 1319: 3-4.

101 Muwaqqar al-Dawlah to Ministry of Foreign Affairs, 9 August 1901/23 Rabi II 1319. In Asnadi az rawabit-i Iran wa Hind: 313 .

102 In this context, tazkirah initially referred to an identity document and eventually to a passport. See Kashani-Sabet, Frontier Fictions: 54-5, 221.

103 Kia, Persianate Selves.

104 Mufakhkham al-Sultan to Ministry of Foreign Affairs, 20 January 1903/20 Shawwal 1320. In Asnadi az rawabit-i Iran wa Hind: 355 . 
fact been settled in Bengal since the first decades of the seventeenth century. ${ }^{105}$ Mufakhkham al-Sultan relayed the shah's affection for them and promised his own careful attention to their affairs. He noted that the Armenians maintained a school in Calcutta with a hundred students, including some from southern Iran. So struck was he by this Persian diaspora that he proposed to undertake a census of "all Iranians, Muslim and Armenian" living in India and to issue each of them identity papers-a daunting task that he acknowledged would require not only money but also, tellingly, knowledge of the "languages of India (zabān-i Hindī)." ${ }^{106}$ The Iranian foreign ministry approved, but it is unclear how far this project developed. ${ }^{107}$

The early Pahlavi government more strenuously enforced Iran's nationality law, but it too was not always successful. In 1924, the Iranian government protested the unilateral deportation of Akali Sikhs by the British consul from Duzdab to India. ${ }^{108}$ In 1925 , the chief Iranian representative in India, Taqi Nabawi, directed consuls to refuse to visa the British passports of "Persians who either through their long stay or birth in India have changed their nationality."109 There was some Qajar precedent here; in 19o1, Muwaqqar al-Dawlah had declined to grant visas in similar circumstances. ${ }^{110}$ In 1925 , such persons were

105 S.D. Aslanian, From the Indian Ocean to the Mediterranean: The Global Trade Networks of Armenian Merchants from New Julfa (Berkeley: University of California Press, 2011): 63-4.

106 Mufakhkham al-Sultan to Ministry of Foreign Affairs, 20 January 1903/20 Shawwal 1320. In Asnadi az rawabit-i Iran wa Hind: 35 o. Traditionally, the Persian phrase "zabān-i Hind" referred to all Indian languages other than Sanskrit. Hindī and Hindūstānī are the adjectival forms of the Arabic and Persian geographic terms Hind and Hindūstān, respectively, which may refer variably to the peoples, climates, styles, and languages of the Indian subcontinent. In the nineteenth century, the term Hindūstānī came to be identified with a north Indian vernacular called Khari Boli, which subsequently split into Hindi (written in Nagari script) and Urdu (written in Perso-Arabic script). For more information, see B.S. Cohn, Colonialism and Its Forms of Knowledge: The British in India (Princeton: Princeton University Press, 1996): 16-56; C.R. King, One Language, Two Scripts: The Hindi Movement in Nineteenth Century North India (New Delhi: Oxford University Press, 1994); I. Bangha, "Rekhta, Poetry in Mixed Language: The Emergence of Khari Boli Literature in North India." In Before the Divide: Hindi and Urdu Literary Culture, ed. F. Orsini (New Delhi: Orient BlackSwan, 2010): 21-83.

107 Mushir al-Dawlah to Mufakhkham al-Sultan, 3 April 1903/5 Muharram 1321. In Asnadi az rawabit-i Iran wa Hind: 363 .

108 M. Koyagi, "Drivers across the Desert: Infrastructure and Sikh Migrants in the Indo-Iranian Borderlands, 1919-1931." Comparative Studies of South Asia, Africa, and the Middle East 39/3 (2019): 381-3.

109 Taqi Nabawi to Vice-Consul, Karachi (trans.), 17 October 1925/25 Mihr 1304, IOR $\mathrm{L} / \mathrm{E} / 7 / 1346$.

110 Muwaqqar al-Dawlah to Ministry of Foreign Affairs, 24 October 1901/11 Rajab 1319. In Asnadi az rawabit-i Iran wa Hind: 321 . 
to surrender their British passports and accept Persian ones if they wanted to travel to Iran. The following year, Lord Lamington, President of the Persian Society, relayed a letter from an unnamed correspondent in Bombay who explained in astonishment that the Iranian consul there had declined a visa to Colonel Merwan Irani, who had served with the Indian Medical Service for twenty-three years. Irani ignored the Bombay consul, somehow obtained a visa at a Persian port, and then "represented the Parsi community at the Coronation of Reza Shah," in April 1926."11 Bombay Persians, Lamington's correspondent observed, "proceed to Persia under a very irregular arrangement. Very many go as British subjects, some go with two passports while others deal with each port of entry according to the circumstances of the day."

For the British, the most high-profile nationality case turned out to be that of Haji Muhammad Hasan Namazi. Namazi was born in Shiraz in 1859 to a mercantile family with business in Hong Kong. ${ }^{12}$ He too became a successful merchant and ship-owner and led the maritime trade of Chinese green tea to Russia via the Black Sea. He lived in Bombay for twelve years before settling for the next thirty in Hong Kong, where he owned considerable commercial real estate and named his racehorses after Iranian mountains. In 1916, he became a naturalized British subject in Hong Kong and was appointed Justice of the Peace in 1921 as a gesture toward the colony's Indian inhabitants. The governor, R.E. Stubbs, explained: "Mr. Nemazee, though of Persian birth, is so closely associated with the Indian community that I think that most people in the Colony would be surprised to learn that he is not an Indian."113 Stubbs also praised Namazi's philanthropic work, especially his gift of HK\$100,0oo to the University of Hong Kong. In 1923, when Namazi and his son, Ahmad, who was born a British subject in Hong Kong in 1901, entered Iran from Iraq near Khanaqin, Persian authorities confiscated their British passports, asserting both men to be Iranians. ${ }^{114}$

British officials would have let the matter drop had it not been for the fact that they alleged Namazi to be the principal opium smuggler between the

111 As quoted in Lamington to Foreign Office, 27 July 1926, IOR L/E/7/1346. For the Indo-Persian Zoroastrian community, see M.M. Ringer, Pious Citizens: Reforming Zoroastrianism in India and Iran (Syracuse: Syracuse University Press, 2011) and Marashi, Exile and the Nation.

112 Chick to Loraine, 15 January 1924, IOR L/E/7/1346; "Aide-Memoire of interview of Mr. Haji Muhammad Hasan Nemazi J.P. (of Hong Kong) with Sir P. Loraine. April 19, 1925. Shiraz," IOR L/E/7/1338; "Mr. H.M.H. Nemazee." The North-China Herald and Supreme Court \& Consular Gazette, 28 August 1935: 345 .

113 Stubbs to Thomas, 7 August 1924, IOR L/E/7/1338.

114 Loraine to Curzon, 18 December 1923, IOR L/E/7/1346. 
Persian Gulf and China. They were determined to destroy his operations, but this task would prove easier said than done. British opium laws varied from colony to colony, and the Namazis navigated them artfully. Hoping to close these loopholes, the British government made it illegal for Hong Kong residents to trade opium without a license in $1924 .{ }^{115}$ In April 1925, Sir Percy Loraine, the minister to Iran, met with Namazi in Shiraz, where he had recently opened a maternity hospital. His most famous son, Hajj Muhammad, who was born in Hong Kong in 1896, would carry on this charitable tradition, founding the Namazi Hospital in Shiraz after World War II. ${ }^{116}$ Loraine warned Namazi senior that Britain was seeking to prosecute him but knew that his status as a Persian national would protect him in Iran, remarking that "my threat was a "brutum fulmen' which Nemazi may be sharp-witted enough to detect."117 The following year, an interdepartmental committee in London drafted the "The Dangerous Drugs Regulations" (1926), prohibiting British subjects from dealing in Iranian opium without a license within the extraterritorial jurisdiction of the consular courts in the Persian Gulf. ${ }^{118}$ Namazi was careful not to break the new opium laws. His eldest son, Aqa 'Ali, had reportedly shifted the family's narcotics business to Bombay, which enjoyed laxer opium laws than did Hong Kong or Bushihr. In the spring of 1926, Namazi left Bushihr on his Persian passport for Hong Kong via Bombay, and the British consul-general was obliged to visa this document as he could not deny a British subject entry into British territories. ${ }^{119}$ Namazi returned again to Shiraz several years later, where he died in 1935 .

Iran's desire to end extraterritoriality, meanwhile, led to the great legal reforms of the early Pahlavi years and the country's greater participation in the arena of international law. In a speech on 26 April 1927 establishing a new national court system, Riza Shah announced the imminent abolition of extraterritoriality and other capitulations. ${ }^{120}$ Tehran withdrew the kārguzāāān from the provinces in June. ${ }^{121}$ The very capable minister of justice, 'Ali Akbar

115 Colonial Office Memorandum, 1926 enclosed in Amery to Guillemard, 21 August 1926, IOR $\mathrm{L} / \mathrm{E} / 7 / 1338$.

116 A. Milani, Eminent Persians: The Men and Women Who Made Modern Iran, 1941-1979, vol. 2 (Syracuse: Syracuse University Press, 2008): 1081-6.

117 Loraine to Chamberlain, 6 May 1925, IOR L/E/7/1338.

118 "The Dangerous Drugs Regulations," 1926, IOR L/E/7/1338.

119 Prideaux to Clementi, 27 March 1926, IOR L/E/7/1338.

120 "The Royal Speech at the Opening of the newly formed Justice Courts," (trans.) enclosed in Clive to Chamberlain, 5 May 1927, CO 732/27/6; Pakravan to Clive (trans.), 12 May 1927, co 732/27/6; Zirinsky, "Riza Shah's Abolition of the Capitulations"; Zandiyah, Tahawwul-i nizam-i qaza’i-yi Iran: 211-7.

121 "Memorandum from Persian Ministry for Foreign Affairs to His Majesty's Legation" (trans.), 13 July 1927, CO 732/27/6; Zandiyah, Tahawwul-i nizam-i qaza'i-yi Iran: 230-1. 
Davar, drafted new criminal, civil, and commercial codes and began organizing the new courts, which prepared Iran to revoke extraterritoriality a year later on 10 May 1928. ${ }^{122}$ Persian officials quickly passed a new nationality law in September 1929. ${ }^{123}$ An English translation was included in a monumental Collection of Nationality Laws of Various Countries prepared for the Conference for the Codification of International Law, which was convened by the League of Nations in 1930 at The Hague. ${ }^{124}$ Iran's delegation was headed by Anushirwan Sipahbudi. The Conference hoped to eliminate "all cases both of statelessness and double nationality."125 These goals proved impossible but clearly enjoyed considerable international support including from Pahlavi Iran.

Iran's 1929 legislation clarified the 1894 law by explicitly embracing both jus soli and jus sanguinis. ${ }^{126}$ Persian nationality was extended to "all residents of Iran,"127 except persons possessing documentary proof of a foreign nationality; to everyone "born in Iran or abroad" to a Persian father; and to everyone born in Iran to a foreigner who was also born in Iran-i.e. double jus soli. ${ }^{128}$ The law thus confirmed the Iranian government's claims over persons of Persian ancestry living abroad, especially in India. It also made many Indians living

122 Floor, "Judicial and Legal Systems"; Ansari, The Politics of Nationalism: 86-91; A. Gheissari, "Constitutional Rights and the Development of Civil Law in Iran, 1907-1941." In Iran's Constitutional Revolution: Politics, Cultural Transformations, and Transnational Connections, ed. H.E. Chehabi and V. Martin (New York: I.B. Tauris, in association with Iran Heritage Foundation, 2010): 69-79; M. Mohammadi, Judicial Reform and Reorganization in 2oth Century Iran: State Building, Modernization, and Islamicization (New York: Routledge, 2008): 80-103.

123 "Persian Law of Nationality as passed by the National Consultative Assembly. Dated Shahrivar 16, 1308 (September 7, 1929)" (trans.), IOR L/E/7/1346.

124 R.W. Flournoy Jr. and M.O. Hudson, ed., A Collection of Nationality Laws of Various Countries as Contained in Constitutions, Statutes, and Treatises (New York: Oxford University Press, 1929): vii, $473-6$.

125 "Convention on Certain Questions Relating to the Conflict of Nationality Laws." In League of Nations, Acts of the Conference for the Codification of International Law, vol. 1, Plenary Meetings (Geneva, 1930): 81 (https://biblio-archive.unog.ch/Dateien/Council MSD/C-351-M-145-1930-V_EN.pdf). In addition to "Nationality," the conference also addressed "Territorial Waters" and "Responsibility of States for Damage Caused in their Territory to the Person or Property of Foreigners." See also, League of Nations, Acts of the Conference for the Codification of International Law, vol. 2, Minutes of the First Committee-Nationality (Geneva, 1930): 241, (https://biblio-archive.unog.ch/Dateien/ CouncilMSD/C-351-(a)-M-145-(a)-1930-V_EN.pdf).

126 "Persian Law of Nationality as passed by the National Consultative Assembly. Dated Shahrivar 16, 1308 (September 7, 1929)" (trans.), IOR L/E/7/1346.

127 "Kullīyah-yi sākinīn-i İrān" in today's Iranian Civil Code (Article 976). See Qanun-i madani (http://rc.majlis.ir/fa/law/show/97937).

128 For double jus soli, see Weil, How to be French: 256-7. 
in Iran Persian nationals. Someone born in Iran to a foreigner could renounce his Persian nationality in favor of his father's foreign nationality within a year of his eighteenth birthday, now with ministerial rather than royal permission, but had to sell or give his real property to an Iranian. Tehran later established procedures for the registration of foreign residents, the compulsory sale of their agricultural properties, and their deportation at the discretion of Iranian officials. ${ }^{129}$ Seeking, furthermore, to balance imports and exports by means of a Trade Monopoly Law in 1931, Iran greatly impaired commerce with India. ${ }^{130}$

Indian communities in Iran were uneasy. As the British consul-general in Mashhad remarked in July 1929,

it is becoming increasingly difficult to remain an undistinguished unit in the flotsam and jetsam of Meshed; either you are a Persian subject and must wear a Pehlavi hat or you should give very good reasons why you should not. At the same time the Census Department is functioning energetically and gathering into its net large numbers of people who have no wish to be enrolled as likely subjects for recruitment into the Persian Army. ${ }^{131}$

One group feeling the pressure were some two hundred Kurramis, whose ancestors hailed from the Indo-Afghan border region and settled in Tehran, Gilan, Mazandaran, and Khurasan. ${ }^{132}$ Their situation was further complicated by the fact that Kurram was an Agency territory, not a formal part of British India; Kurramis were thus British protected persons rather than British subjects. One condition of the new Iranian nationality law was that the foreign state claimed by an individual renouncing Persian nationality had to certify him as a national of that state. The problem was that Kurram did not have a nationality law, and neither for that matter did the Indian princely states of Kashmir and Hyderabad, whose subjects in Iran were also British protected persons. Consequently, in 1931-2 the Government of India directed Kurram,

129 "Law Governing Arrival in, Sojourn in, and Passage through Persia of Foreigners" (trans.), passed 10 May 1931/19 Urdibihisht 1310, IOR L/P\&S/12/3428 Coll 28/31: 59-61 (http://www .qdl.qa/en/archive/81055/vdc_100000000602.oxooo3d6); "Projet de loi relatif aux propriétés ressortissants étrangers en Perse" as appeared in Messager de Tehran and later passed on 7 June 1931/16 Khurdad 1310, IOR R/15/2/146o File 15/17: 45-7 (http://www.qdl .qa/en/archive/81055/vdc_100000000282.0xooooc3).

130 Koyagi, "Drivers across the Desert": 384.

131 Consul-General Mashhad to Foreign Secretary, Government of India, 27 June 1929, IOR $\mathrm{L} / \mathrm{P} \& \mathrm{~S} / 11 / 26$ o P 2649/1925.

132 Clive to Henderson, 26 July 1930, IOR L/P\&S/10/3433 Coll 28/37: 442-3, (https://www.qdl .qa/en/archive/81055/vdc_10000000o6o2.0xooo3db). 
Kashmir, and Hyderabad to issue similar notifications, which, following British law, extended their respective nationalities to the "descendants of ... emigrants born abroad ... for two generations." ${ }^{133}$ This situation not only revealed the "lumpy"134 legal terrain of the British Empire but also was a case in which legal modernity flowed not from Europe to Iran but instead from Iran to British protectorates in the subcontinent. Ultimately such efforts proved futile. The Iranian government decided in 1933 that anyone renouncing Iranian nationality must leave the country. British officials in Iran communicated this information in a circular letter drafted in both English and Persian. ${ }^{135}$ They quietly urged the Kurramis and others to accept Iranian census/identification documents (sijill-i a hwwa $l$ ) and the loss of British diplomatic assistance within Iran. In 1935, Iran again revised the nationality law and incorporated it into the Civil Code. ${ }^{136}$ A person could now renounce Iranian nationality only at age twenty-five, not eighteen, having first completed military service, and must then depart the country.

Hazaras resident in Khurasan soon attracted Iranian attention. Fleeing Afghanistan following rebellions against 'Abd al-Rahman Khan in 1888-1893, some Hazaras settled near Mashhad and others near Quetta. ${ }^{137}$ During World War I the British recruited men from both communities for the "Hazara Pioneers" in eastern Iran. Some of the Quetta Hazaras, who were British subjects, remained in Khurasan after the war. ${ }^{138}$ In 1935, the Iranian government threatened the expulsion of these so-called "British Barbaris" for their alleged, but later disproved, involvement in the demonstrations against the nationalist Pahlavi dress code at the shrine of Imam Riza that had been bloodily suppressed that summer. ${ }^{139}$ In 1938, Mashhad authorities again ordered the deportation of the British Hazaras, citing their refusal to abandon their customary dress and suspecting them of espionage, especially as some of them received military

133 Muhammad Ayyub et al. to the Political Agent, Kurram Agency, 12 August 1931, IOR L/P\&S/10/3433 Coll 28/37: 294; Hyderabad Notification, September 1931, IOR L/P\&S/10/ 3433 Coll 28/37: 257; Maharajah Hari Singh of Kashmir and Jammu, Notification, 28 June 1932, IOR L/P\&S/10/3433 Coll 28/37: 227 .

134 Benton, Search for Sovereignty: xii.

135 Mallet to Consuls, 26 July 1933, IOR L/P\&S/10/3433 Coll 28/37: 64-7.

136 "Civil Code: Book 2 Concerning Nationality, passed by the Majless in its session of $17^{\text {th }}$ [27th] Bahman, 1313 (16th February 1935)” (trans.), IOR L/P\&S/10/3433 Coll 28/37: 34-41.

137 S.A. Mousavi, The Hazaras of Afghanistan: An Historical, Cultural, Economic and Political Study (Richmond, Surrey: Curzon, 1998): 111-38, 142-4, 148-53.

138 Daly, "Note on the Berberis of East Iran," 2 August 1935, IOR L/P\&S/12/3466: 108-13.

139 Kazimi to Knatchbull-Hugessen (trans.), 31 August 1935/8 Shahrivar 1314, IOR L/P\&S/ 12/3466: 164; H.E. Chehabi, "Staging the Emperor's New Clothes: Dress Codes and NationBuilding under Reza Shah." Iranian Studies 26/3-4 (1993): 209-33. 
pensions from the British consul. By August, ninety-eight British Hazaras and thirty-nine other Hazaras had quitted the country. ${ }^{140}$ The British consul in Mashhad, G.F. Squire, urged retaliation by deporting Iranian merchants from India or a negative press campaign. ${ }^{141}$ Britain, however, feared escalation, one Foreign Office official observing two weeks after the Munich Agreement with Hitler that "at the present juncture in world affairs we can hardly embark on a campaign of publicity against the Persians, however much their manners may call for such action."142 Squire and the British Hazaras got their revenge, however unexpectedly, when the Government of Punjab deported sixty-nine Iranian "gypsies" to Mashhad following a riot in Multan that occurred in June $1938 .{ }^{143}$ Punjab authorities took this action purely for local reasons without reference to the ongoing Hazara dispute, much to the surprise of Delhi and London. Squire cheerfully reported that the Governor-General of Khurasan, Fath Allah Pakravan, had traded "harmless Berberis" for "thieves" whom he was now ejecting from Mashhad. ${ }^{144}$

While the Hazara case undoubtedly demonstrated the hardening of national boundaries during the interwar period, a final episode demonstrates that there was still some fleeting room for maneuver within the Persianate, especially for a merchant of means, connections, and tact. In 1932 Haji 'Abd al-Husayn Hyderabadi and other Indian merchants in Chabahar applied to renounce Iranian nationality. A British official sent to investigate in 1934 described Haji 'Abd al-Husayn as "the Raise Tujar, also one of the wealthiest merchants and largest property owner, the expert on Charbar affairs, the 'brains' of all the different communities, and as he proudly describes himself, the 'right hand of Customs and authorities."'145 Haji 'Abd al-Husayn was optimistic about a compromise, especially as he and his father had made powerful allies in Tehran. Later that year, however, many of the petitioners found themselves obliged to accept Iranian nationality documents, including Haji 'Abd al-Husayn, who had been imprisoned until he did. ${ }^{146} \mathrm{He}$ lobbied British authorities for assistance,

140 Butler to Halifax, 5 August 1938, IOR L/P\&S/10/3467: 103-4; Afghan moneylenders were also being pressured to give up their business and leave India in the 1930-4Os, see Warner, "Kabuliwalas": 190-3.

141 Squire to Butler, 6 April 1938, IOR L/P\&S/10/3467: 228-30.

142 Baxter to Peel, 13 October 1938, IOR L/P\&S/3467: 67-8.

143 Metcalfe to Peel, 14 March 1939, IOR L/P\&S/10/3467: 31-2.

144 Squire, Mashhad Diary, December 1938, IOR L/P\&S/12/3467: 42.

145 Lincoln to Gastrell, 6 February 1934, IOR L/P\&S/12/3487: 116.

146 Knatchbull-Hugessen to Kazimi, 15 December 1934, IOR L/P\&S/12/3487: 68-76. 
and they pressed his case with the Iranian government when it appeared he might be put on trial in Kirman for his leadership in the Chabahar dispute. ${ }^{147}$

In the end, however, Haji 'Abd al-Husayn Hyderabadi managed his own affairs very effectively. The Iranian government accepted his nationality renunciation in 1936, whereupon he successfully petitioned Riza Shah to allow him and his family to remain in Chabahar on a residency permit (jawāz-i iqāmat). Others were not so lucky; over two hundred British subjects left the port in January 1937. ${ }^{148}$ Haji 'Abd al-Husayn was soon touring the new road between Zahidan and Chabahar with the new governor-general and selling supplies to Iranian troops in the port. ${ }^{149} \mathrm{He}$ remained mindful of the value of British assistance and, explaining his new situation to the British, remarked that he "brought all the facts to your kind notice and advice so that you may extend your kind help to me in case any trouble comes."150 Evidently there was still some room in Riza Shah's Iran for a well-connected and useful Indian merchant, even one who rejected Iranian nationality and repeatedly appealed to British diplomats in a manner more appropriate to the Qajar era than to the Pahlavi one.

\section{Conclusion}

Much had changed between Muhammad Riza's death in 1893 and Haji 'Abd al-Husayn's reprieve in 1937. Extraterritoriality had been abolished and Iranian nationality stringently defined. Opposition to extraterritoriality and the evolution of Iranian nationality law, nonetheless, forms an important continuity bridging the Qajar and Pahlavi periods. The imperial context is essential for understanding not only Iranian legal reforms in the 1920s but also Iran's entry into the international legal order. Extraterritoriality, moreover, had an enormous impact on Indian communities living in Iran and the Persian Gulf, no doubt offering them legal options and protection but also subjecting them to British rule beyond the Raj. Iran's expansive 1894 nationality law circumscribed extraterritoriality even before the latter's abolition in 1928. Blending Persian and European traditions and extending to populations not only in Iran but also India (and even Hong Kong), Iranian nationality law was a prominent

147 Knatchbull-Hugessen to Willingdon, 24 October 1935, IOR L/P\&S/12/3487: 24-9.

148 Butler to Linlithgow, 5 November 1937, IOR L/P\&S/3487: 8-9.

149 Lincoln to Seymour, 25 September 1937, IOR L/P\&S/12/3487:15-6.

150 Haji 'Abd al-Husayn Hyderabadi to Lincoln, 16 August 1937, IOR L/P\&S/12/3487: 17. 
feature of a Late Persianate legal terrain, but its increasingly exclusive boundaries also helped to bring the Persianate to a close.

By the 1930s, Indian merchants and migrants enjoyed far less flexibility, and many were returning home. British protection had often proved useful to them, but the imposition of Indian law overseas also underscored the imperial inequalities that raised an anti-colonial, Indian consciousness among "expatriate patriots." ${ }^{151}$ British frustrations with Pahlavi intransigence, meanwhile, would soon find an outlet in summer 1941 with the Anglo-Soviet invasion of Iran, which resulted in Riza Shah's abdication and rendered him an exile on the Indian Ocean, first in Mauritius and then in South Africa, where he died three years later. Iranian sensitivity about extraterritoriality resurfaced in 1964 when Ayatollah Khomeini denounced the extension of diplomatic immunity to American military personnel in Iran. ${ }^{152}$ Key sections of the 1935 Nationality Law remain in the Civil Code of the Islamic Republic, ${ }^{153}$ posing considerable difficulties for the Iranian diaspora today. Imperialism's long shadows in Iran include legal ones.

\author{
Appendix \\ Document 1: Kārguzāar to Wilson, 26 January 1894/18 Rajab 1311, \\ FO 248/590
}

Transcription ${ }^{154}$

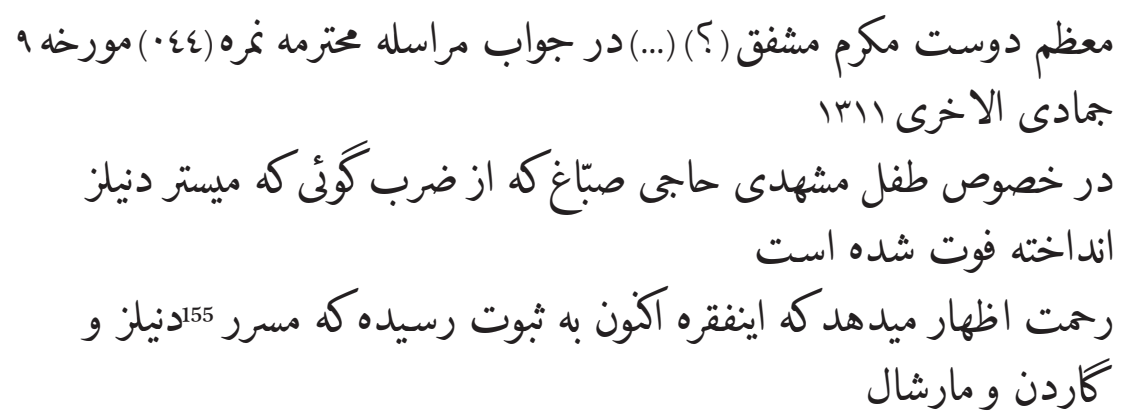

$15^{1}$ Bose, Hundred Horizons: 148-70.

$15^{2}$ N.R. Keddie, Roots of Revolution: An Interpretive History of Modern Iran (New Haven: Yale University Press, 1981): 159; Amanat, Iran: A Modern History, 598-6oo.

153 See Qanun-i madani, Articles 976-991 (http://rc.majlis.ir/fa/law/show/97937).

154 I am most grateful to Mehrbod Khanizadeh and Nandini Chatterjee for their very great help in correcting my errors and filling in gaps in my transcription of this document.

155 Translated as "Messrs" in the British residency translation below. 
در روز وقوع اين حادثه وقتيكه بمردم كُتند كه از دور بازيكاه آنها دور بشوند و

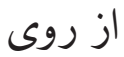
حالت نهذيرفنتد آك احتياط كرده و تزك بازيرا نموده بودند طفل متوفى دهار

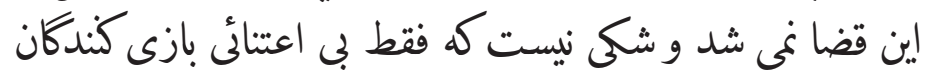

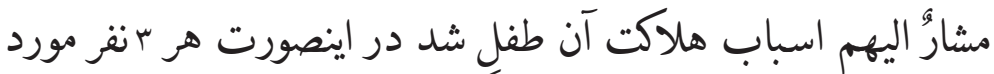

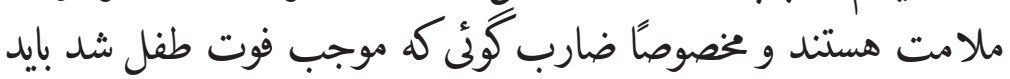

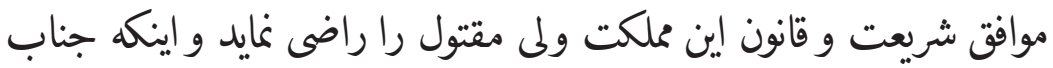

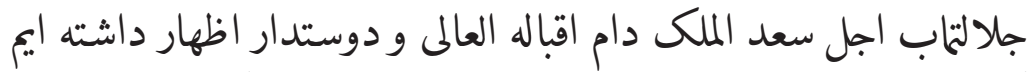

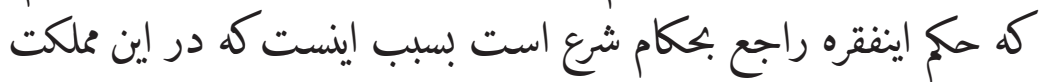

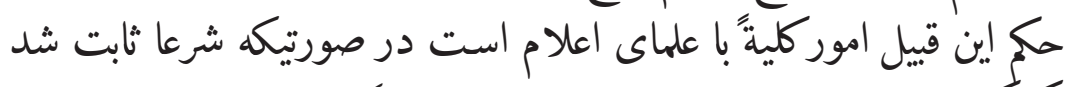

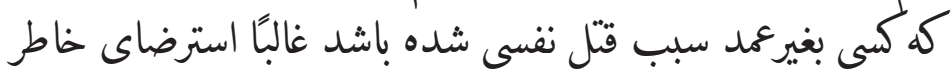

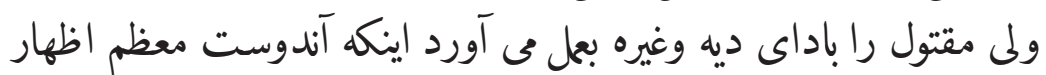

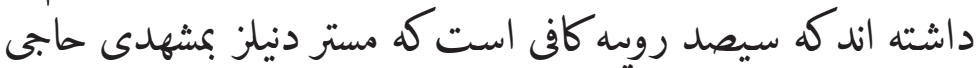

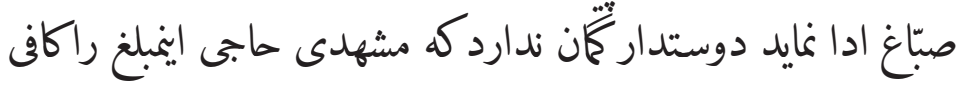
خواهد دانست و باخذان راضى خواهد شد در هر حال انفصال اينقذيه 156 موقوف بر إن است كه مستر دنيلز دركاركذارى حاضر شود و تفصيل واقعه را

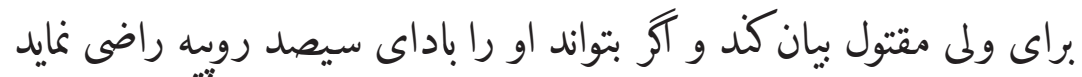

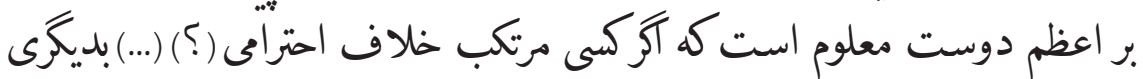
شود مجبور است دو دوست كه براى اعتذار و استرضاى خاطر طرف مقابل حاضر شود و مستر دنيلز بر فزض اينك سهوًا مرتكب قتل اين طفل ايرانى شده باشد بطريق اولى لازم است كه در حضور مامورين دولت عليه إيران با ولى مقتول مواجهه كذد و او را باداى ديه راضى نمايد و عذر خطاى خود رات عاله آرات

156 اينقضيه 


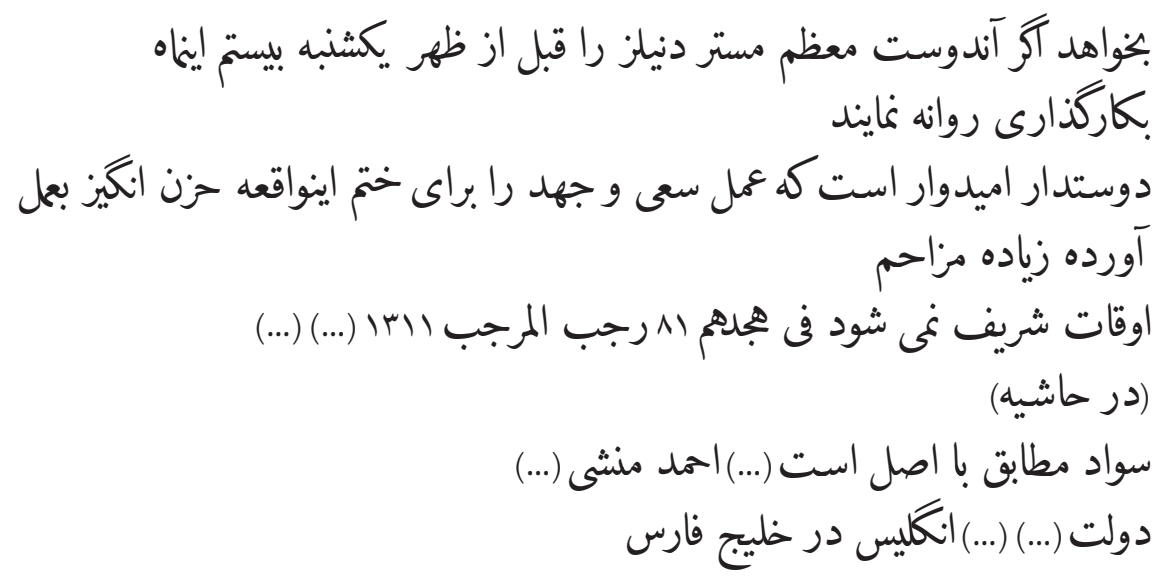

Translation ${ }^{157}$

No. 47

From Karguzar, Bushire

To Resident, Persian Gulf,

Dated 18th Rajab 1311/26th January 1894

A.C. In reply to your letter No: 440 of the 9 th Jamadi-ul Akher 1311/18th December [18]93 regarding the case of the son of Meshedy Haji Sabbagh who died from the blow received from a ball struck by Mr Daniels, I have the honour to state that it has now been proved that if Messrs Daniels, Garden and Marshal[l] had taken the precaution to stop playing when the spectators through ignorance did not heed their warning to stand far from the play-ground, this accident would have been escaped by the lad (deceased). There is no doubt that the carelessness of the players only has resulted in the death of the boy. Under the circumstances all three of them are liable to blame and especially the striker of the ball which was the cause of the boy's death and he should satisfy the guardian of the deceased in accordance with the religious (and civil) laws of this country. The statement made by the Saad-ul-Mulk and me to the effect that the decision of this case rests with the doctors of the religious law, is due to the fact that in this country (the settlement of) such matters are wholly (in the hands of) the Ulema. When it is proved that one has unintentionally been the cause of another's death he has generally speaking to satisfy the guardian of the deceased by paying blood-money \&c.

157 This text is the British residency translation of the Persian copy (Figure 1). Original spelling has been retained. 
As regards your statement that a sum of 300 Rupees is sufficient compensation to be paid by Mr Daniels to Meshedy Haji Sabbagh, I do not think Meshedy Haji will consider this sum sufficient and be satisfied with its acceptance.

Under any circumstances the settlement of this case depends upon Mr Daniels appearing at the Foreign Agency, describing the details of the occurrence to the deceased's guardian and inducing him if possible to accept Rs: $300 /-$.

You are aware that when one is a cause of offence towards another he is obliged to present himself before the offended party to apologise and make amends. Supposing that Mr Daniels was accidentally the cause of death of this Persian boy, it is the more necessary to meet the guardian of the deceased in the presence of the Persian Government authorities and satisfy him by the payment of blood-money and apologise to him for his fault. If you will send Mr Daniels to this Agency before noon on Sunday the 2oth instant/ 28th January 1894, I hope to use my best endeavors for the settlement of this sad case.

Document 2: Articles 1 and 9, Iranian Nationality Law, 1894, $\mathrm{Habl}$ al-matin, no. 28, 22 April 19o1/2 Muharram 1319: 3

\section{Transcription}

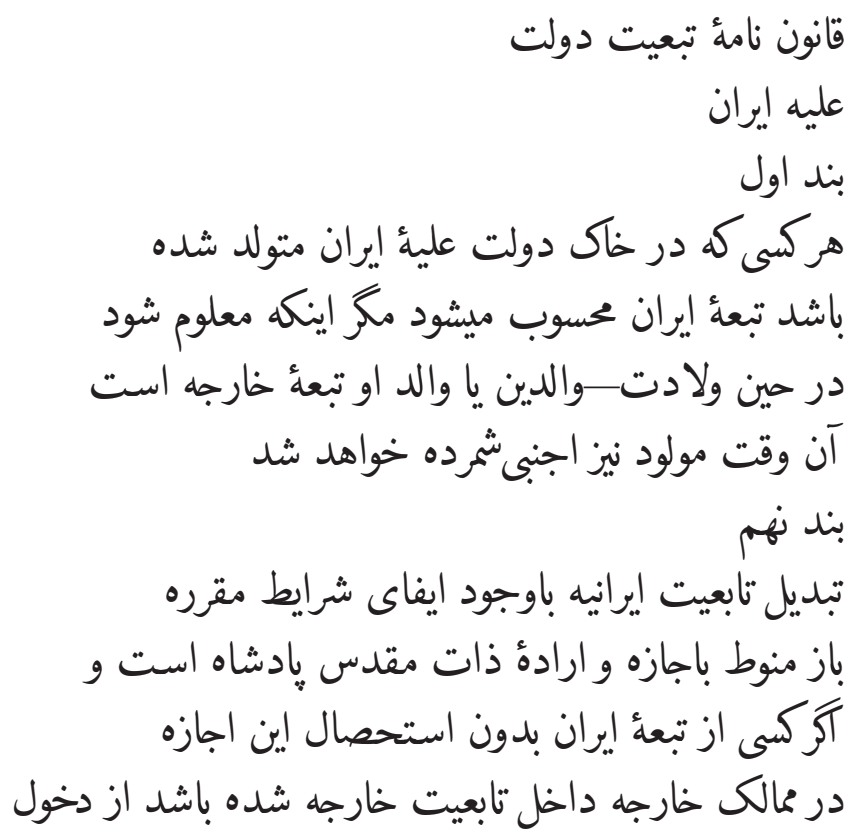




\section{بخاك ايران ممنوع و آك در ايران علاقة از ملك وغيره

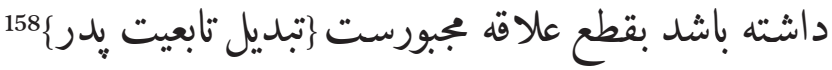

\section{Translation}

The Nationality Law of the Government of

Iran

\section{Article 1}

Anyone born in the territory of the Iranian government is accounted an Iranian national unless it is clear that at the time of birth his parents or his father were foreign nationals in which case he too will be considered a foreigner.

\section{Article 9}

Changing one's Iranian nationality, notwithstanding the conditions stipulated [in Article 8], also depends on the will and permission of the shah. If an Iranian, without obtaining this permission, adopts a foreign nationality while abroad, he is prohibited from entering Iran, and if he has property etc. in Iran, he is obliged to sever these connections.

\section{Acknowledgments}

I wish to thank Nandini Chatterjee, Christoph Werner, and Fahad Bishara for their kind invitation to present this paper to the workshop, "Transactions and Documentation in the Persianate World" at the University of Exeter in 2018 and to publish it here. I also appreciate their helpful comments as well as those of Ali Gheissari, Ghulam Nadri, Elizabeth Thelen, Dominic Vendell, the three anonymous reviewers, and Paolo Sartori and his editorial colleagues at this journal. The staffs at the UK National Archives, the British Library, as well as the La Salle, Princeton, and Swarthmore libraries have been most obliging. I am grateful for a research grant from La Salle University. I thank the European

$15^{8}$ Incorrectly printed under Article 9-belongs to Article 10. 
Research Commission and the Lawforms project for providing funds to publish this article, and the entire issue, in Open Access format.

\section{Bibliography}

\section{Archival Sources}

co Colonial Office, UK National Archives, Kew, Richmond.

FO Foreign Office, UK National Archives, Kew, Richmond.

IOR India Office Records, British Library, London.

QDL Qatar Digital Library.

\section{Published Primary Sources}

British and Foreign State Papers, 170 vols. 1812-1968. Hein Online.

Flournoy, Richard W., Jr. and Manley O. Hudson, ed. 1929. A Collection of Nationality Laws of Various Countries as Contained in Constitutions, Statutes, and Treatises. New York: Oxford University Press.

Foreign Office Documents on Persia 1899-1913, 16 reels. 197os. University of Chicago microfilm.

Habl al-matin. 1893-1930.

Jalali Farahani, Ahmad, ed. 1997/1376. Asnadi az rawabit-i Iran wa Hind dar dawrah-yi Muzaffar al-Din Shah Qajar. Tehran: Wizarat-i Umur-i Kharijah, Mu’assasah-yi Chap wa Intisharat.

Journal du droit international privé et de la jurisprudence comparée, 41 vols. 1874-1914. Hein Online.

League of Nations. 1930. Acts of the Conference for the Codification of International Law, vol. 1 Plenary Meetings (https://biblio-archive.unog.ch/Dateien/CouncilMSD/C-351 -M-145-193o-V_EN.pdf) and vol. 2. Minutes of the First Committee-Nationality (https://biblio-archive.unog.ch/Dateien/CouncilMSD/C-351-(a)-M-145-(a)-193o-V _EN.pdf). Geneva.

Matine-Daftary, Ahmad Khan. 1930. La suppression des capitulations en Perse: l'Ancien régime et le statut actuel des étrangers dans l'Empire du "Lion et Soleil." Paris: Les presses universitaires de France.

Qanun-i madani, Articles 976-991 (http://rc.majlis.ir/fa/law/show/97937).

Stack, Edward. 1882. Six Months in Persia, 2 vols. London: Sampson Low, Marston, Searle \& Rivington.

Sykes, Percy. 1902. Ten Thousand Miles in Persia or Eight Years in Iran. London: John Murray.

The North-China Herald and Supreme Court \& Consular Gazette. 1870-1941. ProQuest Historical Newspapers: Chinese Newspapers Collection. 


\section{Secondary Literature}

Amanat, Abbas. 2017. Iran: A Modern History. New Haven: Yale University Press.

Amanat, Abbas and Assef Ashraf, ed. 2019. The Persianate World: Rethinking a Shared Sphere. Boston: Brill.

Amin, Camron Michael. 2015. The Press and Public Diplomacy in Iran, 1820-1940. Iranian Studies 48/2: 269-87.

Anghie, Antony. 2005. Imperialism, Sovereignty, and the Making of International Law. New York: Cambridge University Press.

Ansari, Ali M. 2012. The Politics of Nationalism in Modern Iran. Cambridge: Cambridge University Press.

Aslanian, Sebouh David. 2011. From the Indian Ocean to the Mediterranean: The Global Trade Networks of Armenian Merchants from New Julfa. Berkeley: University of California Press.

Atabaki, Touraj. 2008. Constitutionalism in Iran and its Asian Interdependencies. Comparative Studies of South Asia, Africa, and the Middle East 28/1: 142-53.

Bamdad, Mahdi. 1968/1347. Sharh-i hal-i rijal-i Iran dar qarn-i 12 wa 13 wa 14 hijri, 6 vols. Tehran: Intisharat-i Zawwar.

Bangha, Imre. 2010. Rekhta, Poetry in Mixed Language: The Emergence of Khari Boli Literature in North India. In Before the Divide: Hindi and Urdu Literary Culture, ed. Francesca Orsini. New Delhi: Orient BlackSwan: 21-83.

Benton, Lauren. 2001. Law and Colonial Cultures: Legal Regimes in World History, 14001900. New York: Cambridge University Press.

Benton, Lauren. 2010. A Search for Sovereignty: Law and Geography in European Empires, 1400-1900. New York: Cambridge University Press.

Bishara, Fahad Ahmad. 2017. A Sea of Debt: Law and Economic Life in the Western Indian Ocean, 1780-1950. Cambridge: Cambridge University Press.

Bose, Sugata. 2006. A Hundred Horizons: The Indian Ocean in the Age of Global Empire. Cambridge: Harvard University Press.

Burak, Guy. 2015. Between the Kāanūn of Qāytbāy and Ottoman Yasaq: A Note on the Ottomans' Dynastic Law. Journal of Islamic Studies 26/1: 1-23.

Calmard, Jean. 1988/2020. Bast. Encyclopaedia Iranica Online (http://dx.doi.org/10.1163/ 2330-4804_EIRO_COM_6726).

Chaudhuri, K.N. 1985. Trade and Civilisation in the Indian Ocean: An Economic History from the Rise of Islam to 1750. Cambridge: Cambridge University Press.

Chehabi, Houchang E. 1993. Staging the Emperor's New Clothes: Dress Codes and Nation-Building under Reza Shah. Iranian Studies 26/3-4: 209-233.

Cohn, Bernard S. 1996. Colonialism and Its Forms of Knowledge: The British in India. Princeton: Princeton University Press.

Cole, Juan. 2002. Iranian Culture and South Asia, 1500-1900. In Iran and the Surrounding World: Interactions in Culture and Cultural Politics, ed. Nikki R. Keddie and Rudi Matthee. Seattle: University of Washington Press: 15-35. 
De, Rohit and Robert Travers. 2019. Petitioning and Political Cultures in South Asia: Introduction. Modern Asian Studies 53/1: 1-20.

Flatt, Emily J. 2017. Practicing Friendship: Epistolary Constructions of Social Intimacy in the Bahmani Sultanate. Studies in History 33/1: 61-81.

Floor, W.M. 1977. Bankruptcy in Qajar Iran. Zeitschrift der Deutschen Morgenländischen Gesellschaft 127/1: 61-76.

Floor, Willem. 2009/2020. Judicial and Legal Systems v. Judicial System in the 2oth Century. Encyclopaedia Iranica Online (http://dx.doi.org/10.1163/2330-4804 _EIRO_COM_11032).

Fransman, Laurie, et al. 2011. British Nationality Law. Haywards Heath, West Sussex: Bloomsbury Professional, third edition.

Gheissari, Ali. 2010. Constitutional Rights and the Development of Civil Law in Iran, 1907-1941. In Iran's Constitutional Revolution: Politics, Cultural Transformations, and Transnational Connections, ed. H.E. Chehabi and Vanessa Martin. New York: I.B. Tauris, in association with Iran Heritage Foundation: 69-79.

Gheissari, Ali. (forthcoming). Unequal Treaties and the Question of Sovereignty in Imperial Persia. In Struggles for Sovereignty: Non-European Powers in the Age of Empire, ed. Houchang E. Chehabi and David Motadel. Oxford University Press.

Gilbar, Gad G. 2011. Resistance to Economic Penetration: The Kārguzār and Foreign Firms in Qajar Iran. International Journal of Middle East Studies 43: 5-23.

Green, Nile. 2011. Bombay Islam: The Religious Economy of the West Indian Ocean, 18401915. Cambridge: Cambridge University Press.

Green, Nile, ed. 2019. The Persianate World: The Frontiers of a Eurasian Lingua Franca. Oakland: University of California Press.

Good, Peter. 2019. The East India Company's Farmān, 1622-1747. Iranian Studies 52/1-2: 181-97.

Gustafson, James. 2016. Kirman and the Qajar Empire: Local Dimensions of Modernity in Iran, 1794-1914. New York: Routledge.

Hanley, Will. 2017. Identifying with Nationality: Europeans, Ottomans, and Egyptians in Alexandria. New York: Columbia University Press.

Hayyim, Sulayman. New-Persian English Dictionary, (https://dsal.uchicago.edu/diction aries/hayyim/).

Hodgson, Marshall G.S. 1977. The Venture of Islam: Conscience and History in a World Civilization, 3 vols. Chicago: University of Chicago Press, paperback edition.

Hurewitz,J.C., ed. 1975. The Middle East and North Africa in World Politics: A Documentary Record, 3 vols. New Haven: Yale University Press, second edition.

Kashani-Sabet, Firoozeh. 1999. Frontier Fictions: Shaping the Iranian Nation, 1804-1946. Princeton: Princeton University Press.

Kashani-Sabet, Firoozeh. 2013. Baluchistan: Nature, Ethnicity, and Empire in Iran's Borderlands. Journal of the Middle East and Africa 4: 187-204. 
Kayaoğlu, Turan. 2010. Legal Imperialism: Sovereignty and Extraterritoriality in Japan, China, and the Ottoman Empire. New York: Cambridge University Press.

Keddie, Nikki R. 1981. Roots of Revolution: An Interpretive History of Modern Iran. New Haven: Yale University Press.

Kern, Karen M. 2011. Imperial Citizen: Marriage and Citizenship in the Ottoman Frontier Provinces of Iraq. Syracuse: Syracuse University Press.

Kia, Mana and Afshin Marashi. 2016. Introduction: After the Persianate. Comparative Studies of South Asia, Africa, and the Middle East 36/3: 379-83.

Kia, Mana. 2016. Indian Friends, Iranian Selves, Persianate Modern. Comparative Studies of South Asia, Africa, and the Middle East 36/3: 398-417.

Kia, Mana. 2020. Persianate Selves: Memories of Place and Origin Before Nationalism. Stanford: Stanford University Press.

King, Christopher R. 1994. One Language, Two Scripts: The Hindi Movement in Nineteenth Century North India. New Delhi: Oxford University Press.

Koyagi, Mikiya. 2019. Drivers across the Desert: Infrastructure and Sikh Migrants in the Indo-Iranian Borderlands, 1919-1931. Comparative Studies of South Asia, Africa, and the Middle East 39/3: 375-88.

Lewis, Mary Dewhurst. 2008. Geographies of Power: The Tunisian Civil Order, Jurisdictional Politics, and Imperial Rivalry in the Mediterranean, 1881-1935. The Journal of Modern History 80/4: 790-831.

Marashi, Afshin. 2008. Nationalizing Iran: Culture, Power, and the State, 1870-1940. Seattle: University of Washington Press.

Marashi, Afshin. 2020. Exile and the Nation: The Parsi Community of India and the Making of Modern Iran. Austin: University of Texas Press.

Markovitz, Claude. 2000. The Global World of Indian Merchants, 1750-1947: Traders of Sind from Bukhara to Panama. Cambridge: Cambridge University Press.

McKeown, Adam M. 2008. Melancholy Order: Asian Migration and the Globalization of Borders. New York: Columbia University Press.

Mehta, Uday Singh. 1999. Liberalism and Empire: A Study in Nineteenth-Century British Liberal Thought. Chicago: University of Chicago Press.

Metcalf, Thomas R. 2007. Imperial Connections: India in the Indian Ocean Arena, 18601920. Berkeley: University of California Press.

Milani, Abbas. 2008. Eminent Persians: The Men and Women Who Made Modern Iran, 1941-1979, 2 vols. Syracuse: Syracuse University Press.

Mitchell, Colin. 1997. Safavid Imperial Tarassul and the Persian Inshä Tradition. Studia Iranica 26: 173-209.

Mohammadi, Majid. 2008. Judicial Reform and Reorganization in 2oth Century Iran: State Building, Modernization, and Islamicization. New York: Routledge.

Mousavi, Sayed Askar. 1998. The Hazaras of Afghanistan: An Historical, Cultural, Economic and Political Study. Richmond, Surrey: Curzon. 
Nabavi, Negin. 2009/2020. Journalism i. Qajar Period. Encyclopaedia Iranica Online (http://dx.doi.org/10.1163/2330-4804_EIRO_COM_4061).

Nouraei, Morteza and Vanessa Martin. 2005. The Role of the 'Karguzar' in the Foreign Relations of State and Society of Iran from the mid-nineteenth century to 1921. Part I: Diplomatic Relations. Journal of the Royal Asiatic Society, 3rd ser., 15/3: 261-77. Nouraei, Morteza and Vanessa Martin. 20o6a. The Role of the 'Karguzar' in the Foreign Relations of State and Society of Iran from the mid-nineteenth century to 1921. Part II: The 'Karguzar' and Security, the Trade Routes of Iran and Foreign Subjects 19001921. Journal of the Royal Asiatic Society, 3rd ser., 16/1: 29-41.

Nouraei, Morteza and Vanessa Martin. 20o6b. The Role of the 'Karguzar' in the Foreign Relations of State and Society of Iran from the mid-nineteenth century to 1921. Part III: The 'Karguzar' and Disputes over Foreign Trade. Journal of the Royal Asiatic Society, 3rd ser., 16/2: 151-63.

Onley, James. 2014. Indian Communities in the Persian Gulf, c. 1500-1947. In The Persian Gulf in Modern Times: People, Ports, and History, ed. Lawrence G. Potter. New York: Palgrave Macmillan.

Parvin, Nassereddin. 2002/2020. Habl al-matin. Encyclopaedia Iranica Online (http:// dx.doi.org/10.1163/2330-4804_EIRO_COM_2576).

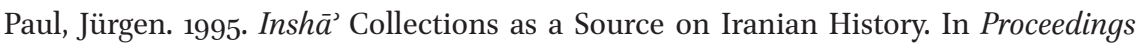
of the Second European Conference of Iranian Studies, ed. B.G. Fragner et al. Rome: Istituto Italiano Per Il Medio Ed Estremo Oriente: 535-5o.

Potter, Lawrence G. 2017. Society in the Persian Gulf: Before and After Oil. Occasional Paper 18. Center for International and Regional Studies, Georgetown University in Qatar.

Ringer, Monica M. 2011. Pious Citizens: Reforming Zoroastrianism in India and Iran. Syracuse: Syracuse University Press.

Schneider, Irene. 2006. The Petitioning System in Iran: State, Society and Power Relations in the late 19th Century. Wiesbaden: Harrassowitz.

Sharafi, Mitra. 2010. The Marital Patchwork of Colonial South Asia: Forum Shopping from Britain to Baroda. Law and History Review 28/4: 979-1009.

Stebbins, H. Lyman. 2016. British Imperialism in Qajar Iran: Consuls, Agents and Influence in the Middle East. London: I.B. Tauris.

Tavakoli-Targhi, Mohamad. 2001. Refashioning Iran: Orientalism, Occidentalism, and Historiography. New York: Palgrave.

Torpey, John. 2000. The Invention of the Passport: Surveillance, Citizenship, and the State. New York: Cambridge University Press.

Vejdani, Farzin. 2015. Making History in Iran: Education, Nationalism, and Print Culture. Stanford: Stanford University Press. 
Vejdani, Farzin. 2016. Indo-Iranian Linguistic, Literary, and Religious Entanglements: Between Nationalism and Cosmopolitanism, ca. 1900-1940. Comparative Studies of South Asia, Africa, and the Middle East 36/3: 435-54.

Warner, H William. 2020. The Kabuliwalas: Afghan moneylending and the credit cosmopolis of British India, c. 1880-1947 The Indian Economic and Social History Review 57/2: 171-98.

Weil, Patrick. 2008. How to be French: Nationality in the Making since 1789. Durham: Duke University Press.

Yeganeh, Naser. 1991/2020. Citizenship iii. In Modern Times (Qajar and Pahlavi Periods). Encyclopaedia Iranica Online (http://dx.doi.org/10.1163/2330-4804_EIRO _COM_7738).

Zandiyah. Hasan. 1392/2013. Tahawwul-i nizam-i qaza'i-yi Iran dar dawrah-yi Pahlavi-yi awwal ('asr-i Wizarat-i Adliyah-yi 'Ali Akbar Davar) (Qum: Pizhuhishgah-yi Hawzah wa Danishgah, 1392/2013).

Zia-Ebrahimi, Reza. 2016. The Emergence of Iranian Nationalism: Race and the Politics of Dislocation. New York: Columbia University Press.

Zirinsky, Michael. 2003. Riza Shah's Abolition of the Capitulations, 1927-1928. In The Making of Modern Iran: State and Society under Riza Shah, 1921-1941, ed. S. Cronin. New York: Routledge: 81-98. 